IZA DP No. 6873

Promotion and Wages in Mid-Career:

Gender, Unionism, and Sector

John T. Addison

Orgul Demet Ozturk

Si Wang

September 2012 


\title{
Promotion and Wages in Mid-Career: Gender, Unionism, and Sector
}

\author{
John T. Addison \\ University of South Carolina \\ and IZA \\ Orgul Demet Ozturk \\ University of South Carolina \\ Si Wang \\ University of South Carolina
}
Discussion Paper No. 6873
September 2012

\author{
IZA \\ P.O. Box 7240 \\ 53072 Bonn \\ Germany \\ Phone: +49-228-3894-0 \\ Fax: +49-228-3894-180 \\ E-mail: iza@iza.org
}

Any opinions expressed here are those of the author(s) and not those of IZA. Research published in this series may include views on policy, but the institute itself takes no institutional policy positions. The IZA research network is committed to the IZA Guiding Principles of Research Integrity.

The Institute for the Study of Labor (IZA) in Bonn is a local and virtual international research center and a place of communication between science, politics and business. IZA is an independent nonprofit organization supported by Deutsche Post Foundation. The center is associated with the University of Bonn and offers a stimulating research environment through its international network, workshops and conferences, data service, project support, research visits and doctoral program. IZA engages in (i) original and internationally competitive research in all fields of labor economics, (ii) development of policy concepts, and (iii) dissemination of research results and concepts to the interested public.

IZA Discussion Papers often represent preliminary work and are circulated to encourage discussion. Citation of such a paper should account for its provisional character. A revised version may be available directly from the author. 
IZA Discussion Paper No. 6873

September 2012

\section{ABSTRACT}

\section{Promotion and Wages in Mid-Career: Gender, Unionism, and Sector}

This paper considers the role of gender in the promotion process and the impact of promotion on wages and wage growth, using data from the National Longitudinal Survey of Youth (NLSY79). Its focus is upon mid-career promotion and wages, thereby complementing extant studies of the NLSY79 that relate to differences between men and women at an earlier stage in their careers. The paper is further differentiated from these studies and the wider promotions literature in considering the role of unionism and the public sector. It is reported that mid-career females are more likely than males to be promoted in the private sector (and no less likely in the public sector); that wages are increasing in promotion, and the effect is generally higher for females; and that female wage growth from contemporaneous promotion is almost as high as that for males in the private sector and much higher in the public sector. These rather positive results for females represent in most cases an improvement over the early-career findings but in mid-career the mediating influence of unionism is more negative, and not just for females.

JEL Classification: J16, J31, J51, J62

Keywords: mid-career, early career, promotion, wages, wage growth, gender, unionism, public sector

Corresponding author:

John T. Addison

Department of Economics

Moore School of Business

University of South Carolina

Columbia, SC 29208

USA

E-mail: ecceaddi@moore.sc.edu 


\section{Introduction}

The role of gender differences in promotion rates is the subject of a growing albeit unsettled literature. Furthermore, that literature has expanded of late to consider the consequences of promotion. Without seeking to minimize the differences in finding and interpretation that have arisen, there is now broad agreement that promotion plays a material role in general earnings development. The promotions literature has thus come to supplement a much older literature on the earnings function while contributing independently to the discussion of labor market structure and job hierarchies. But, as we have intimated, there are real disagreements regarding the impact of gender on promotion and thence on earnings development. Mixed results are indicative in part of a literature that has typically examined a single firm (or small group of firms) or single occupation and/or that has a basis in cross-section analysis. Only a limited number of studies use representative samples of workers across occupations and firms, and even fewer use panel data estimation techniques. One goal of the present paper is to contribute to the debate by presenting new evidence on gender and promotion using a longer panel than the latter. In particular, we shall examine a panel that encompasses mid-career development and not just early careers. Accordingly, we shall investigate a broader 'slice’ of the job hierarchy.

The panel dataset through which we seek to offer a general analysis of gender as a factor in promotion and provide unbiased estimates of its effects is the 1979 National Longitudinal Survey of Youth (NLSY79), a sample of approximately 12,000 young males and females aged 14 to 22 years in 1979. The survey has a number of strengths. First, it is a nationally representative sample offering results that can be generalized. Second, and to repeat, since the data in question cover 30 years of a respondent's work history, they allow us to track progress over a reasonably long career profile. Third, in providing alternative definitions of what it means 
to be promoted, the dataset offers additional detail typically lacking from other representative datasets. Further, the NLSY79 has detailed occupational controls that allow us to merge in skills and task measurement data to the survey.

Although the NLSY79 has been used before in investigating the gender and promotion issue, the present study not only examines a distinct career profile but also investigates the influence of unionism as well as broad sector (viz. public versus private). Both entities might be expected to mediate the gender-promotion-earnings nexus, although neither has been addressed other than in passing in the modern promotions literature. For its part, unionism may be expected to emphasize seniority systems, which could mean that unions exert a positive effect on promotions, unless the sample is dominated by workers at the start of their careers (as is the case with extant NLSY79 studies). Modern unions, if not their predecessors, might place especial weight on reducing gender differentials, perhaps even reversing some productivity-based differentials, on policy grounds. On the other hand, if unions substantially narrow wage differentials at the workplace then this may translate into shorter job ladders to begin with so that the union effect on promotions and earnings growth may be at best much attenuated and the main effect observed through wage levels. Less positively, insider-outsider considerations may ensure that the interests of women are not reflected in union policy making circles.

For its part, the public sector is of interest because it might conceivably be in the vanguard of programs involving equal or even preferential treatment for women. Also, job assignment might be more structured than in the private sector, with formalized hierarchies and longer promotion ladders. That said, the public sector may be sheltered from competition, permitting more discrimination than a competitive private sector. But the latter aspect, and the fact that union density today is much higher in the public sector, means that the interaction 
between public sector and unionism must receive equal billing.

\section{Gender and Promotion in the Literature}

Past research on the determinants and consequences of promotion has tended to focus on individual firms or occupations, particularly the former, the rationale being that across-firm differences in promotion practices (and wage growth) will be either ruled out or that the definition of a promotion will be rendered more transparent. The obvious limitation of such approaches is that their results may not be generalizable. More representative studies using larger samples of workers and firms may, then, tell us more about which patterns are relevant to the average worker. But to the extent that such studies are based on cross-section data, they too will also confront causality issues raised by unobserved individual heterogeneity. Panel data such as those used in the present study hold out real promise in this regard while also enabling us to consider the dynamic relationship between promotion and compensation.

Firm studies ${ }^{1}$

Firm studies investigating promotions alone include Stewart and Gudykunst (1982), Cannings (1988), Jones and Makepeace (1996), Spilerman and Petersen (1999), and Fernandez and Abraham (2011). Stewart and Gudykunst (1982) examine the promotion process for males and females based on a survey questionnaire distributed to a stratified random sample of employees working in a large financial organization in the Northeast in 1980. The authors examine determinants of hierarchical level (i.e. job grade) and number of promotions. Their

\footnotetext{
${ }^{1}$ For occupational analyses, the reader is referred in particular to studies of lawyers by Spurr (1990) and Spurr and Sueyoshi (1994), and of academics in the humanities and economics by Ginther and Hayes (1999, 2001) and McDowell, Singell, and Zilliak (2001). These studies provide clear evidence of discrimination against women on the basis of their promotional experience. Nevertheless, all studies report major improvement in gender gaps - typically their elimination - over time.
} 
covariance and multiple regression analysis of each suggest that females received more promotions than males but occupied significantly lower positions in the organizational hierarchy. Number of promotions and hierarchical level were positively correlated for males alone.

Cannings (1988) analyzed promotion in a large Canadian service-sector corporation on the basis of questionnaires sent to middle managers. The author's fitted logit model suggested that women were only 80 percent as likely as males to be promoted in any given year of their careers with the firm. Cannings interpreted the female promotion deficit as indicating that women hit an invisible ceiling.

A more nuanced view is expressed by Jones and Makepeace (1996) in a British study of the personnel records of a large financial institution in 1988. The authors' ordered probit model reveals that that the thresholds necessary to secure promotion to the various grades are materially greater for women than for men. But much of the difference between men and women reflected their attributes, and in particular women's lack of work experience. Further, the greatest barriers confronted by women were found at the lower but not the higher reaches of the job ladder. Evidence of lower female promotion in the lower job classifications is also found by Spilerman and Petersen (1999) in their study of organizational structure and promotion in a large insurance company. Women are found to be concentrated in the clerical jobs that are subject to ceiling grade barriers. The overall female promotion rate was 84 percent of the male rate. In the senior grades, however, it was 1.43 times the male rate.

Fernandez and Abraham’s (2011) study of hiring for some 1,669 positions in a large U.S. biosciences company is novel by virtue of its focus on internal and external hiring. The authors investigate gender sorting across all 21 levels of this company’s organizational hierarchy. After taking into account the gender composition of the pools of candidates from which the hires were 
selected, the authors conclude that, although the percentage of females declines along the hierarchy, women are more likely to be hired than males. In the case of external hires, women are more likely to be hired than males and there is no indication that this pattern declines with the level of the job position. ${ }^{2}$

Finally, firm studies investigating promotion and its wage consequences include Gerhart and Milkovich (1989), Hersch and Viscusi (1996), and Ransom and Oaxaca (2005). In their study of promotion in a manufacturing firm, Gerhart and Milkovich (1989), report that promotions had a similar impact on earnings for males and females but that females had more promotions. Hersch and Viscusi (1996) offer a more pessimistic interpretation of their finding of higher promotions among female than male employees of a public utility. The authors' negative binomial regression model of the number of promotions received provides evidence of differential promotion rates in favor of women and also that quits caused by spousal job moves (predominantly affecting women) are associated with more promotions. Given that their OLS wage regressions reveal strong gender differences in the effect of (the number of) promotions on wages in favor of males, however, they conjecture that the promotion result stems from women starting lower on the job ladder, mechanically providing more scope for promotions, with joint job search constraining women.

Ransom and Oaxaca (2005) examine promotion and wage differences in a retail grocery store chain. The authors report evidence of a high level of job segregation because of the near exclusive assignment of some entry-level jobs to women and their virtual exclusion in practice from management positions. Female hourly paid workers earned 8.3 percent less than males after

\footnotetext{
${ }^{2}$ The main lesson of this study is that both internal and external 'risk sets' are necessary to understand the routes through which males and females progress or gain access to upper level jobs.
} 
allowing for seniority and age, but only 1.5 percent less after controlling for the job title of the employee, so that differences in job assignment explain almost all of the gender gap in pay. Probit regressions indicate that the estimated probability of promotion to a store-level management position of male food clerks over the four-year sample period was six times that of female food clerks.

Industry studies

Industry studies include Cabral, Ferber, and Green (1981), DiPrete and Soule (1988), and Pekkarinen and Vartiainen (2006). In their study of gender differences in wages across four occupational categories - manager, professional, technical and sales, and clerical/service/blue collar groups - in three large fiduciary institutions, Cabral, Ferber, and Green (1981) found that women receive lower initial job placements than males, and, where employed in similar entry positions, are differentially promoted after being hired. ${ }^{3}$

DiPrete and Soule (1988) examine gender differences in promotion rates in the federal civil service in the 1970s, exploiting the boundaries between job ladders, job ladder groupings, and tiers. The chief finding is that gender promotion differs by grade level. The authors logistic regression analysis shows that women who attain administrative or professional journeyman levels have the same rate of subsequent advancement as males: they worked on job ladders that were structured to offer the same opportunity for advancement as males. The main source of difficulty confronting females occurred in the middle grades where the rate of advance was much lower than that of males mainly by reason of job ladders that had a ceiling in the middle grades. It was also much more difficult for female to obtain promotions from lower tier to upper tier job

\footnotetext{
${ }^{3}$ See also McDowell and Court (1994) for an inter-disciplinary study of the social construction of gendered identities at work and for preliminary results from a case study of the gendering of a range of occupations in the financial services sector in the city of London.
} 
ladders.

Pekkarinen and Vartiainen (2006) offer a test of the Lazear and Rosen (1990) model, using a decade of panel data on Finnish metal workers to investigate gender differences in the allocation of workers across jobs of different complexity. The authors measure promotions using changes in the complexity of the job (indexed by the log occupation-related wage) performed by the worker. ${ }^{4}$ Having controlled for the complexity of the initial job assignment, they report significant gender differences; specifically, females move up the complexity ladder in smaller steps than do males who started in jobs of similar complexity. This finding also receives support from duration (to promotion) analysis. On net, while promotion prospects are more frequent the less complex the initial job assignment, it is found that females who tend to start their career in such jobs are less likely than male incumbents to move up to more complex tasks. Finally, the authors exploit productivity comparisons using data on personal bonuses. There is no indication of gender productivity differentials at the time of initial assignment. Thereafter, however, both promoted and non-promoted women are rated more productive, implying higher promotion thresholds for women.

\section{Studies Based on More Representative Samples or Panel Data}

We turn in conclusion to studies based on the Quality of Employment Panel, the Panel Study of Income Dynamics, the Multi-City Study of Urban Inequality, the British Household Panel Survey, and the 1979 National Longitudinal Study of Youth also used in the present empirical inquiry.

In a panel study of intra-occupational earnings differences using the Quality of

\footnotetext{
${ }^{4}$ See also the Austrian study of Winter-Ebmer and Zweimüller (1997), using microecensus data, where promotion is measured by the holding a job with formal skill requirements beyond the observed level of schooling.
} 
Employment Panel, 1973-77, Olson and Becker (1983) first confirm that promotion contributes massively to earnings development (cf. Brown, 1989). But the authors' fixed effect regression results suggest that while gender wage gains are equal, ceteris paribus, promotional opportunities are not. Echoing the industry studies, women are found to be held to a higher promotional standard than males. As a result, although the gender earnings gap narrowed by some 6 percent over the sample period, it would have narrowed by roughly 9 percent had men and women been promoted on the basis of the same criteria.

In a much larger-scale study, McCue (1996) presents data on promotions involving a change in position from the 1976-88 survey years of the Michigan Panel Study of Income Dynamics. Promotions are compared with separations and transfers as well as with no changes in position. As far as wage growth is concerned, the author's estimates of the effects of promotion on wages relative to an absence of any change in position are approximately 10 percent for white males and black women and slightly above (below) this for white women (black men). These values pertain to first decade in the labor market. Turning to the incidence of internal mobility, the author's hazard rate results for promotions indicate that black males, black females, and married white females (though not white females as a group) have lower hazards than white males. Finally, the incidence of promotions (and other position changes) is increasing in wages: better paid workers are more likely to be promoted.

Blau and Devaro (2007) consider gender differences in promotion rates and remuneration in their analysis of a sample of new hires from the Multi-City Study of Urban Inequality (see also Devaro and Brookshire, 2007). The authors' probit analysis of promotion suggests that promotion rates are between 2.2 and 3.1 percentage points higher for men than women - where the mean promotion rate is around 9 percent - and is effectively unchanged with the inclusion of 
detailed controls for occupation and industry. The authors' wage-change-from-promotion regressions and within-job wage growth regressions (i.e. without promotion) show little difference between men and women, and are supported by the standard Oaxaca decompositions.

By way of contrast, Booth, Francesconi, and Frank (1999) obtain very different results in an analysis of the 1991-1995 waves of the British Household Panel Survey (BHPS). The British raw data indicate that women are just as likely as men to be promoted each year (11.6 versus 9.2 percent) but receive significantly lower earnings upon promotion (9.8 percent versus 20.4 percent). Controlling for observed and unobserved heterogeneity, the former result goes away but the latter is sustained; for example, if both genders experience 3 promotions, men would receive real wage growth of 32 percent and women just 7 percent.

This brings us to research using the 1979 National Longitudinal Study of Youth (NLSY79). In the first such study, Pergamit and Veum (1999) consider the correlates and consequences of promotion using data from the 1988, 1989, 1990 (and 1996) waves of the NLSY. The authors estimate probit equations for promotion receipt between 1989 and 1990. For promotions as a whole, there are sharp gender differences favoring males. As far as the wage consequences of promotion are concerned, the authors first-differenced wage equations indicate that promotion increased wages on average by approximately 8 percent between 1989 and 1990 . Gender differences were not statistically significant. Longer-term impacts of promotion on wages were obtained by considering wage gains over the period 1989-1996. Wage growth from earlier promotion was now around 12 percent, with some differentiation by type of promotion; in particular, 'noncompetitive' promotions led to larger short-term gains than did 'competitive' promotions although the latter had a longer-lasting impact. Interestingly, although gaining in the long term from competitive promotions, females registered no short-term gains from such 
promotions, leading the authors to conjecture that women might be more likely than men to sacrifice short-term wage gains to undergo career changes.

The most recent cet. par. NLSY79 study is by Cobb-Clark (2001). The main difference between the two studies ${ }^{5}$ is that Cobb-Clark seeks to decompose the gender gap in promotions (and earnings) into differences arising from characteristics and in returns to those characteristics. A secondary difference is that she only considers wage change more or less contemporaneous with promotion. Cobb-Clark's random effects probit model indicates that women have a 5.8 percentage point lower probability of being promoted than corresponding males. ${ }^{6}$ Differences in the returns to characteristics (demographic, human capital, and job) explain the entire promotion gap. The author's log wage growth equation points to wage gains for females that are 2.4 to 5.6 percent higher than for promoted men. At promotion, women experience between 7.0 to 8.1 percent extra wage growth; for men the relative payoff is less than 4.6 percent. The decomposition exercise now reveals a divergence in outcomes between women who get ahead and women who get left behind.

\section{Summary}

The literature presents mixed results both with respect to promotion and its consequences by gender. This diversity is found across the range of studies reviewed above, and in part would seem to reflect differences in definitions of promotion between studies (as is implied by the results contained in individual studies that are able to deploy alternative measures). Not surprisingly, there has also been theoretical disputation as to which gender modern notions

\footnotetext{
${ }^{5}$ See Cobb-Clark and Dunlop (1999) for a descriptive treatment of the (diminishing) gender gap in promotion using data from 1989-90 and 1996 NLSY79.

${ }^{6}$ Cobb-Clark distinguishes between two types of promotion: those in which job responsibilities had increased and those where the promoted individual reported to a different supervisor. Both definitions produce smaller estimates of the gender gap in promotion: of 3.8 percentage points in the former case and just 1 percentage point in the latter case.
} 
exploiting better labor market alternatives might apply. By the same token there are also some commonalities, perhaps the two most important of which are the relevance of promotion to earnings development (particularly in the case of women) and the improvement in the position of females over time, even if the sources of that improvement are contested. Another is the intriguing suggestion, even if only sporadic in the literature, that unionism, and perhaps the public sector as well, might be associated with lower internal mobility.

\section{Data}

We use the core cohort of the NLSY79, offering a nationally representative panel of data for the cohort of individuals aged 14 to 22 years in 1979 who have been interviewed regularly since that year. The core data exclude the oversample of low income youth and also the military. In addition, we do not consider individuals who are self-employed, or who work for no pay. Indeed, we focus only upon those individuals who have worked more than 35 hours a week and for at least 40 weeks in the previous calendar year, so as to avoid considering wage changes resulting from transitions between part-time jobs and full-time jobs (in either direction) in our analysis. In conjunction with the exclusion of those with missing information on any of the variables used in the analysis (including hourly wages, or the reporting of implausible hourly wages), these restrictions yielded a sample comprises 23,875 person-year observations over 10 waves of the survey - 1988, 1989, 1990, 1996, 1998, 2000, 2002, 2004, 2006, and 2008. The 10 waves in question are those in which promotion questions are asked. We focus our analysis on the 19962008 waves of the data, although we shall compare promotions and wages during these years (which we term 'mid-career' for our cohort aged 31-39 years in 1996) with the corresponding outcomes for the 1988-1990 waves (the ‘early-career’ years for individuals aged 23 to 31 years 
in 1988) ${ }^{7}$

The NLSY79 has a number of advantages over other data sets. One is that we can obtain the individual's actual labor market experience from the number of weeks worked since the last interview. This corrects for the potential measurement error in the standard experience measure based on age and education since women may work more discontinuously than men. Another advantage of the survey is that it contains detailed information on promotions, beginning in 1984, then annually between 1988 and 1990, and finally biennially from 1996 onwards (since the survey itself became biennial in 1994). Nevertheless, the promotion question has changed over time, requiring adjustments in our data selection and analysis. In the 1988, 1989, and 1990 surveys, the promotion question relates to promotion on the current job for employees that have worked with the current employer for at least nine weeks. However, this tenure condition no longer attaches to the promotion questions in surveys conducted after 1996. Accordingly, for these years, we applied an additional filter restricting our sample to workers with at least nine weeks of tenure with their current employer. Irrespective of the tenure condition, however, the promotion question always concerns in-house promotions, namely with the current employer, so that all promotions are internal in nature. Nevertheless, we shall also include a dummy variable for a change in employer since the last interview because individuals who are new at their jobs may be less likely to be promoted by reason of not having accrued enough time on the job to

\footnotetext{
${ }^{7}$ We should note that promotion-related questions were also asked in 1984. However, no measure of firm size was collected in this survey year. As we wish to include this standard argument, our baseline analysis will therefore exclude 1984. That said, excluding (dummies for) firm size did not affect the signs or significance levels of the coefficients of interest, other than marginally in one case, even though firm size is a significantly positive determinant of promotion probability, log wages, and log wage growth. Full results for the extended interval are available from the authors upon request.
} 
demonstrate their performance or sufficient tenure to qualify for promotions that are automatic in nature. Conversely, these circumstances might lead to a greater probability of promotion; for example, a woman who changes jobs by reason of her husband's relocation may accept a job for which she is overqualified, and thence rise quickly in the new job hierarchy.

There have also occurred changes over the life of the survey in the type of promotions that respondents are asked to report. Most notably, the promotion question since 1996 asks about promotions that are position changes, whereas the earlier surveys do not impose this restriction. So as to be able to compare our mid-career results with early-career estimates - and also to effect comparisons with the literature - we sought to net out those promotions that did not involve any position change in the 1988, 1989, and 1990 survey responses. To this end, and following Pergamit and Veum (1999), we only code promotions that increase responsibility as a "true" promotion in these early years. ${ }^{8}$

Union membership or coverage data is also collected in different ways across different waves of the NLSY79, which will require us to analyze the effect of unions in different ways for different data periods and also to devise a common definition of unionism to secure comparable results. Over the early survey years - 1988, 1989, and 1990 - individuals were initially asked if they were covered by a collective bargaining agreement. If they answered in the affirmative, respondents were then asked if they were a union member. For these years, we take coverage as the union variable of interest. After 1994, the union affiliation question was asked first and then the coverage question asked only of those responding in the negative (i.e. the non-union

\footnotetext{
${ }^{8}$ And for those waves of the survey on which our analysis focuses, namely 1996-2008, respondents were also asked the reason for their promotion: "reorganization of the company"; "change in ownership"; "company growth"; "others are laid off”; "my job performance”; it was automatic"; and "I requested it". We will address some of the more interesting differences in these reasons in our descriptive analysis.
} 
members). Since we cannot identify coverage for each individual for these later years, we shall use union membership status as one of the definitions of unionism. In the interests of comparability with the earlier period, however, we shall also work with a 'unified' measure of unionism embracing those who are either union members or covered by a union agreement in a composite definition, and assume that all union members are covered. ${ }^{9}$ Descriptive tables will illustrate how this change in definition affects the sample characteristics of our various groups. We used the composite measure of unionism as our baseline definition.

Although labor market activity has been surveyed in great detail in the NLSY79 since its inception, the occupational codes are not recorded consistently across each wave of the survey. Between 1979 and 2000, the occupations are coded according to both the 1970 and 1980 census codes. After 2002, however, jobs are exclusively identified using the 2000 codes to capture the new and emerging occupations. We mapped these occupation codes so as to be able to study the full extent of the promotion data panel available to us. Specifically, we used the crosswalks provided by Meyers and Osborne (2005) and by Acemoglu and Autor (2011) to match all occupation codes in the NLSY79 to the 2000 Census Occupation Codes (COCs). This yielded some 431 occupations for our final sample. Previous studies have shown that using detailed occupational classifications reduces the estimated gender wage gap (Blau and Kahn, 1997; Macpherson and Hirsch, 1995), and we shall assume here that such occupational effects are a reflection of choice and a further means of controlling for heterogeneity. However, we cannot control for all 431 occupations due to degrees of freedom concerns and possible identification

\footnotetext{
${ }^{9}$ Further, due to an error in the questionnaire, information on union affiliation and collective bargaining status was not collected for a number of employees in 1994. Specifically, 1,130 of the employed individuals in our final sample were not asked the unionism question (i.e. whether they were union members and, if not, whether they were nonetheless covered on the job by a collective bargaining agreement). We chose to impute values for this key question, using a methodology similar to that of Booth, Budd, and Munday (2009).
} 
issues. We therefore converted each occupation to a set of tasks/skills after Autor, Levy, and Murnane (2003). These unique standardized indices are defined in Table 1.

Finally, just as is the case with occupations, industries are not coded consistently in the NLSY79. In the 1979 through 2000 surveys, industries are classified according to 1970 codes. Beginning in 2002, the 2000 census codes are used. To match the industry codes, we first use the mapping provided in the Census Bureau’s Technical Report \#59. We then used the NLSY79 Young Adult Attachment 4 to match all codes to those of 1990. Finally, we merged in the 2000 industry codes using the crosswalks provided by the U.S. Census Bureau.

[Tables 1 and 2 near here]

Table 1 gives the means and standard deviations as well as the description of the variables we use in our analysis. Table 2 reports these descriptive statistics by gender, sector, and unionism. About 14 percent of males and 21 percent of females work in public sector, and about 23 percent of males and 20 percent of females are either in unions or are covered by collective bargaining agreements across all sectors. Union affiliation or coverage is much higher among the public sector employees, averaging 55 percent for males and 53 percent for females. The corresponding values are 18 percent and 11 percent in the private sector. Alternatively, stratifying on the basis of union membership per se would yield slightly lower values of worker representation, with 47 percent (15 percent) of males and 41 percent ( 8 percent) of females being union members in the public (private) sector.

Tenure with the current employer is higher for workers with union affiliation irrespective of gender and sector, while overall labor market experience is more or less constant at around 20 years on average for all groups (albeit slightly higher for union affiliated workers). Union affiliated workers have fewer years of education and lower AFQT scores compared to non- 
affiliated workers in private sector, but this is definitely not the case in the public sector. The public sector employs more non-white employees, but more of these workers are union affiliated or covered by collective bargaining in the private sector. Union affiliation or coverage is also more common in medium size (100-500 employees) and large (500+) firms than in their smaller counterparts ( $<100$ employees).

If we were to compare union members to the more generally defined union group containing both union members and covered non-members (the second and third columns by sector), there are few differences, but union members do have slightly more tenure with their current employer throughout. Although we will present results using both definitions, as intimated above we will use the more general definition as our baseline in the interests of consistency when effecting comparisons across periods.

Table 2 also provides descriptive statistics on the type of skills and tasks performed at each job. We see that the types of jobs that are unionized are quite different from non-union jobs in the private sector for both males and females. There are also differences, though not as striking, in public-sector jobs by unionism.

\section{[Table 3 near here]}

Table 3 provides descriptive statistics on real wages and wage growth, as well as promotion for the same set of groupings as Table 2. Observe that real pay levels are significantly lower for women than for men, for all four baseline groups examined. ${ }^{10}$ Moreover, the private sector pays more than the public sector, and this difference is again larger for males. It can also be seen that both genders are less likely to be promoted when they are affiliated with unions or covered by collective bargaining. As was noted earlier, the survey asks the respondents follow-

\footnotetext{
${ }^{10}$ Results for union membership by sector and gender mirror those for the composite unionism measure and are not separately discussed here.
} 
up questions regarding the reason for their promotion, and the table also gives the conditional probabilities in this regard for males and females in four groups. Even though there are seemingly material economic variations in the stated reason for promotion by gender, none of these differences is statistically different. However, in the case of males, promotions that are requested are significantly more common among unionized workers in the public sector, while promotions that are automatic are significantly more common in the private sector, and those that are based on performance are significantly less common for union affiliated workers. Automatic and requested promotions may not produce the same level of returns as do promotions based on performance which are significantly less likely in private sector under unionism. Among females we do not observe any statistically significant differences across sectors or unionism.

\section{The Empirical Model}

We do not structurally model promotion probability, wages, and wage growth and instead follow the same theoretical framework as Cobb-Clark (2001) in modeling our empirical approximations. In this approach, the probability that worker $i$ of gender $g$ ( $g=$ male or female) working in sector $s\left(s=\right.$ public or private) will obtain a promotion at time $t$ in the then current job Prom $_{\text {igst }}=$ 1) is determined as a function of index $\mathrm{Y}$ - let us call it an index of promotability after CobbClark - which is defined as follows:

$$
Y_{i g s t}=\alpha_{g s u}+\beta_{g s} X_{i t}+\varepsilon_{i g s t}
$$

where $X_{i t}$ is a vector of the worker's demographic, human capital and job related characteristics, such as education, AFQT score, marital status, and number of children, tenure with the current employer, labor market experience prior to the current employer, the skills/tasks set required by the job, the local unemployment rate, collective bargaining coverage/union status, and the sector 
and industry of the job. In our estimations we allow the effects of individual and job characteristics to differ by gender and by sector, and therefore estimate separate vectors of $\beta$ for each gender and sector combination. Moreover, we allow the intercept, $\alpha$, to vary not only by gender and sector but also by unionism $(u)$ as well. In addition, for each outcome indicator we estimate versions of the model in which we alternately constrain $\beta$ to be the same for everyone but allow $\alpha$ to vary by sector, gender, and unionism, or to be same for everyone within each gender but $\alpha$ to vary by sector and unionism. These constrained models will be reported in the first three columns of each set of results. Finally, $\varepsilon_{i g s t}$ is the unobserved factors that determine the promotion probability at time $t$ for worker $i$ of gender $g$ in sector $s$.

We first estimated the promotion model treating the data as pooled cross-section using logistic regression and then the preferred panel version using conditional logistic regression with fixed effects. All the estimations were undertaken using STATA 11. Previous studies (Booth, Francesconi, and Frank, 1998; Cobb-Clark, 2001) used a random-effect (RE) model to estimate the gender gap in promotion.

In modeling wage levels and changes in wages, we will estimate not only the effect of unions in the public and private sectors but also the proportion of wage growth that is attributable to promotion. The underlying log wage (level) equation is:

$$
\ln W_{i g s t}=\lambda_{g s u}+\gamma_{g s} X_{i t}+\operatorname{PromCount}_{i t}\left(\theta_{g s}+\zeta_{g s} \text { unionism }_{i t}\right)+v_{i g s t},
$$

where PromCount $i t$ is the number of promotions received by individual $i$ by time $t$ over all periods he/she is observed at the then current job, and unionism is the union or coverage indicator. The error term in this equation comprises an individual fixed effect and a random component where the former is allowed to be correlated with all covariates. We estimate models of the log wage equation for each gender and sector separately, allowing $\lambda, \gamma, \zeta$ and $\theta$ to vary 
across models. We also estimate models with constraints on these parameters similar to those described above for the promotion models.

Given the log wage equation, wage growth is defined as:

$$
\Delta \ln W_{i g s t, t-1}=\ln W_{i g s t}-\ln W_{i g s t-1} .
$$

This wage growth equation ${ }^{11}$ factors out the fixed individual unobserved, allowing us to estimate the following expression using OLS:

$$
\Delta l n W_{i g s t, t-1}=\gamma_{g s}\left(X_{i t}-X_{i t-1}\right)+\operatorname{Prom}_{i g s t}\left(\theta_{g s}+\zeta_{g s} \text { unionism }_{i t}\right)+v_{i g s t}-v_{i g s t-1},
$$

where Prom $_{\text {igst }}$ indicates a promotion (or otherwise) since the last interview (at time $t$-1) with the current employer. We also allow the change in unionism status (and not just contemporaneous unionism) and change in sector, together with their interactions, to differentially effect the contribution of promotion to current wage growth in all specifications.

In the interests of comparison, we shall also estimate promotion probability, log wage, and wage growth equations for the early-career observations in addition to these baseline specifications. These results are formally remitted to the Appendix but are discussed below.

\section{Findings}

First consider the determinants of promotion probability. Table 4 reports the coefficient estimates from cross-sectional and panel fixed effects models with different constraints on the intercepts and slopes, as described in section IV. For each broad model, we first report estimates in which all individuals are pooled and only the intercepts are allowed to differ by gender,

\footnotetext{
${ }^{11}$ Since the current employer may be a new employer, the previous wage is not necessarily the wage received immediately before the promotion but rather with the employer the worker had at the date of last interview.
} 
unionism, and sector.

Beginning with the female coefficient estimate, we see that females are 20 percent more likely to be promoted $\left(\mathrm{e}^{0.185}=1.203\right)$ than their male counterparts among those private-sector workers who are not union members or covered by a collective agreement. This result contrasts sharply with the early part of the career of these workers, when such females were about 15 percent less likely to be promoted $\left(\mathrm{e}^{-0.16}=0.852\right)$ than the corresponding males (see Appendix Table A.1). We also see in this very first model that even though unionism does not bring about a significant shift in the promotion probability for private sector males, if a female is in a union or is covered by collective bargaining her odds of promotion are about 35 percent less $\left(\mathrm{e}^{-0.428}=\right.$ 0.652) than her union-affiliated male counterpart in the private sector. If not a union member or covered but working in the public sector she is 37 percent more likely to be promoted than her private-sector female counterpart $\left(\mathrm{e}^{0.404-0.091}=1.368\right)$, even if she is less likely to be promoted than her fellow non-unionized male public-sector employees $\left(\mathrm{e}^{-0.091}=0.913\right)$. However, this last difference is not significant. We also see that compared to private-sector unions, workers with union affiliation in the public sector are 24 percent less likely $\left(\mathrm{e}^{-0.28}=0.756\right)$ to be promoted, though again this difference is not significant.

[Table 4 near here]

We next relax our constraint on the slope coefficients and allow demographic, firmrelated and other characteristics to differentially affect male and female promotion performance. In this new set of results - shown in the second and third columns of Table 4 - we still allow intercepts to differ by sector and unionism, but not the slope estimates. This second set of results enables us to take a cleaner look at the effects of unionism and public sector employment on the promotion probabilities of males and females separately. We see that compared to their non- 
union affiliated counterparts, females in the private sector are about 41 percent less likely to be promoted $\left(\mathrm{e}^{-0.525}=0.592\right)$. Even though females in the public sector are more likely to be promoted than their private-sector counterparts $\left(e^{0.265}=1.303\right)$, the negative effect of unionism is even larger if they are in the public sector $\left(\mathrm{e}^{-0.525-0.143}=0.513\right)$. Nevertheless, the difference between public sector and private sector is not significant for union affiliated workers. For males, as for females, we see an even larger boost to promotion probability from employment in the public sector. Unlike females, however, unionism does not significantly reduce their probability of promotion: although public sector unionism does imply a 28 percent reduction $\left(\mathrm{e}^{-0.291-0.041}=\right.$ 0.717) in promotion probability, this result is statistically insignificant.

Expecting unions to have different structure and functions by sector, we now turn to models with separate slope coefficients by gender and by sector. The results are given in the next four columns of the table and allow us to zero in on the role of unionism by sector separately for males and females. Looking at the unionism coefficient, we see that the effects of unionism are negative in cross-section for females in both sectors. Specifically, females with union affiliation are 42 percent less likely $\left(\mathrm{e}^{-0.548}=0.578\right)$ to be promoted in the private sector and about 48 percent less likely to be promoted in the public sector $\left(\mathrm{e}^{-0.646}=0.524\right)$ compared to the females with no such affiliation. Males also have a lower probability of promotion in if they are union members or covered by collective bargaining. In this instance, however, the effect is neither economically nor statistically significant in the private sector. And even though the detrimental effect (an odds ratio of $\mathrm{e}^{-0.318}$ ) is significant in public sector, it is substantially less than observed for females.

Looking beyond unionism, gender, and sector, we see that tenure with the firm, firm size, changing jobs, and unemployment also contribute materially to promotion probability. Tenure 
with the firm decreases that probability consistently for both males and females irrespective of sector. This result might appear counterintuitive at first blush but its strength is a reflection of the fact that most of our respondents will have been with their firms for about a decade and will likely be already high up on the career ladder, offering less scope for internal mobility with the passage of time. More obvious perhaps is the increase in promotion opportunities occasioned by increases in firm size. For its part, unemployment negatively impacts promotion probability; in public sector jobs, however, employees' opportunities for promotion seem to be more protected against macroeconomic shocks. Being new to the employer also significantly reduces promotion probability, other than for females in the public sector where the effect is positive but statistically insignificant. We also see that compared to early years of our data (Appendix Table A.1), the negative promotion probability associated being black or Hispanic (especially for males in private sector), no longer exists in the mid-career years for these workers.

Even though we are controlling for the industry and occupation of the individual (by incorporating the types of tasks/skills required on the job), we believe there remain unobserved heterogeneities contributing to promotion probability. The next seven columns of Table 4 exploit the panel nature of our data and estimate the self-same models by introducing an individualspecific intercept that we allow to be correlated with the covariates of our models. It can be seen that our earlier conclusions with respect to the effects of tenure with the firm, firm size, unemployment, and being a new employee carry over from the cross-sectional estimates. However, our earlier estimates regarding the role of unionism and sector seemingly reflect the effect of individual unobserved factors. In particular, in the panel estimates the negative effect of unionism is no longer significant in the private sector, either for males or females. This shows a significant improvement for males compared to the early-career years, as reported in the 
corresponding columns of Appendix Table A.1. Even though there is a huge public-sector boost to promotion for females $\left(\mathrm{e}^{0.700}=2.013\right.$ in the second column of the panel results in Table 4), this effect is substantially reversed if the employee is affiliated with unions. Looking at the union effect separately by sector indicates a lower probability of promotion for both genders that is statistically significant in the public sector (viz. $\mathrm{e}^{-0.608}$ and $\mathrm{e}^{-0.658}$ for females and males, respectively). $^{12}$

\section{[Table 5 near here]}

We are interested in promotion probability mainly because of the consequences. There should be something about a promotion that differentiates it from a wage gain (Pergamit and Veum 1999: 590). Accordingly, we next move on to discussion of our log wage and wage growth estimates, emphasizing the role of promotion history along with unionism, gender, and sector. The log wage level models are contained in Table 5. We only report the fixed effects results and in presenting the models follow the structure of Table $4 .^{13}$ Thus, the first model restricts all the slope coefficients to be constant; that is, we restrict each year of tenure, labor market experience, and so on, to change the wage by the same percentage for males and females regardless of their sector or union affiliation but allow for separate intercepts by gender, sector, and unionism. In these log-level models, our coefficient estimates are “semi-elasticities.” We see that, all else constant, private-sector males have 12.5 percent $\left(e^{0.118}-1\right)$ higher wages when they are union members and/or covered by collective bargaining and there is no statistically significant gender difference. The public sector pays 21.6 percent $\left(\mathrm{e}^{-0.243}-1\right)$ less than the private

\footnotetext{
12 If we restrict our unionism measure to include union members alone (i.e. excluding those nonunionized individuals who are nonetheless covered), the effect of unionism is significantly more negative for females in the public sector and for males in the private sector while it effectively disappears for females in the private sector and is no longer significant for males in the public sector. These results are presented in Appendix Table A.2.

${ }^{13}$ Results from a random effects specification are available from the authors upon request.
} 
sector to males in non-unionized jobs and this public/private sector disparity is lower for females at just 7.9 percent $\left(\mathrm{e}^{-0.243}+\mathrm{e}^{0.128}-2\right)$, cet. par. In this instance, the gender difference is significantly different from zero. When in union-affiliated jobs, male public-sector employees make 1.7 percent less $\left(\mathrm{e}^{0.118}+\mathrm{e}^{-0.153}-2\right)$ than their non-union affiliated counterparts. Females, on the other hand, make significantly more in the public sector compared to their non-union affiliated counterparts $\left(\mathrm{e}^{0.118}+\mathrm{e}^{-0.153}+\mathrm{e}^{0.118}-3\right)$. Even though the gender difference, which is about 12.5 percent $\left(e^{0.118}-1\right)$, is not statistically different from zero, the union effect is both economically and statistically significant.

Looking at the coefficient estimates for the variable "number of promotions [received]," we see that in our most restrictive model each promotion contributes about 15 percent $\left(\mathrm{e}^{0.137}-1\right)$ to the wages of males in the private sector who are not union affiliated and a little more than that $-\left(\mathrm{e}^{0.137}+\mathrm{e}^{0.003}-2\right)-$ for females. In this model, it can be seen that unionism reduces returns to each promotion by about 11 percent $\left(\mathrm{e}^{-0.113}-2\right)$ in the private sector. In the public sector, however, males make about 5 percent more per promotion $\left(\mathrm{e}^{0.148}+\mathrm{e}^{-0.113}-2\right)$ when unionized and the public-private sector discrepancy is statistically different for union-affiliated workers. This effect, however, is reversed for females in unions in public sector. Compared to females who are not union affiliated, these women have 18 percent $\left(\mathrm{e}^{0.148}+\mathrm{e}^{-0.266}+\mathrm{e}^{-0.113}-3\right)$ lower returns to each promotion, all else constant. That is, they not only have a lower probability of promotion compared to their non-union counterparts, they also receive significantly lower returns if they are promoted.

When we relax some of our constraints on the coefficients and allow males and females to have different semi-elasticities with respect to demographic and firm-specific characteristics, we observe that females in the private sector receive about the same percentage increase from 
union affiliation as do males ( $\mathrm{e}^{0.114}-1=0.121$ versus $\left.\mathrm{e}^{0.121}-1=0.129\right)$, but significantly lower wages from public sector employment $\left(\mathrm{e}^{-0.123}-1=-0.116\right.$ versus $\left.\mathrm{e}^{-0.214}-1=-0.193\right)$. Being a union member or covered by collective bargaining in the public sector implies even lower wages for all workers, but only significantly so for males $\left(\mathrm{e}^{-0.174}-1=-0.160\right)$. We see that the returns to each promotion are significantly higher for females than males in the private sector $\left(\mathrm{e}^{0.205}-1=\right.$ 0.228 compared with $\left.\mathrm{e}^{0.094}-1=0.099\right)$. Moreover, while both males and females suffer a reduction in this return for being union affiliated, this effect is only significant for males. Males in private sector unions make 11 percent less than non-union private employees $\left(\mathrm{e}^{-118}-1\right)$. However, for those in the public sector the returns to each promotion are significantly higher for males under unionism, namely by 17.6 percent $\left(\mathrm{e}^{0.162}-1\right)$ compared to their unorganized/uncovered counterparts. On the other hand, unionized females in public sector jobs lose about 11 percent (albeit not significant) compared with their non-union counterparts.

Since these results imply differences across sectors for both males and females, we turn finally to models that allow all of our slope coefficients to vary by sector as well as by gender, and estimate separate intercepts by unionism so as to focus on the effect of unions on earning in general and on the returns to promotion in particular. In this most flexible setup, we see that although unionism is positively associated with wages the effect is only significant for males in the private sector (a wage increase of 10.8 percent) and for females in the public sector (23.5 percent). So even though females are less likely to be promoted when affiliated with unions in the public sector, they are more likely to have higher wages. This is true for males and females in the private sector who are less likely to be promoted at union-affiliated jobs - but this result is now only statistically significant in the case of private-sector males. Moreover, focusing on the effects of promotions, we see that there are positive returns to internal mobility across the board, 
ranging from 8.1 percent $\left(\mathrm{e}^{0.708}-1\right)$ in the private sector for males to almost 65 percent $\left(\mathrm{e}^{0.498}-\right.$ 1) percent for females in the public sector (a huge return but recall that these are rare events for females). These returns are lowered in the presence of unionism; significantly so for females in the public sector by about 19 percent $\left(\mathrm{e}^{-0.209}-1\right)$ and for males in the private sector by about 10 percent $\left(\mathrm{e}^{0.107}-1\right){ }^{14}$

When we compare these unionism and sector effects to those for the early-career years presented in Appendix Table A.3, we observe that the impact of unionism is now positive throughout and statistically significantly so for females in the public sector and males in the private sector. We also observe significantly higher returns per promotion for both genders in mid-career as compared with the early-career years with the exception of public sector males. However, unionism now seems to reduce the earnings increment per promotion for females in the public sector and males in the private sector.

We next turn to the wage growth equation, and focus on the contribution of being promoted in different sectors for males and females under unionism. From the first model, we observe that wage growth is some 6.3 percent higher under unionism (union membership and/or coverage). ${ }^{15}$ A change in earnings of opposite sign is observed if the individual becomes a public sector employee between time $t-1$ and $t$; namely, a 6.4 percent reduction in earnings. Even though there is a large bump in earnings from getting a promotion (of 12.6 percent) in the private sector, if the promoted worker is a union member or covered by a union contract then the gain

14 These estimates are based on the composite unionism measure. When we instead define unionism as union membership per se, we detect only modest differences between Table 5 and Appendix Table A.4. However, it does appear that the negative effects of unionism on the returns per promotion are weaker (stronger) for males (females) using the membership definition.

${ }^{15}$ Note that the unionism variable can be either 1 if the worker moves to a union job from a nonunion job, or his/her employer adopts collective bargaining, or -1 if the reverse occurs, and will be 0 if there is no change in union status. 
from promotion is just over 4 percent less than for a currently unaffiliated worker - although this reduction is not statistically significant. Interactions between changes in public sector status and union status cover four dummy outcomes: from public-sector union job to private-sector nonunion job; from private-sector non-union job to public-sector union job; from public-sector nonunion job to private-sector union job; and, finally, from private-sector union job to public-sector non-union job. The dummy value will be 1 for the first two movements, and -1 for the last two (and will be zero when only sector or union status changes). As a practical matter, however, the effect is not statistically significant for either positive or negative values.

[Table 6 near here]

Turning to our results by gender, constraining the slope coefficients to be same for both sectors, we see that the impact of becoming a union member is positive for both males and females but only (marginally) significantly so for females. Even though becoming a public employee serves to dampen wage growth, the effect again is only significant for females (at 9.4 percent). Promotion brings about positive earnings growth for all, but promotion-induced wage growth is significantly higher for females than for males (13.3 percent versus 10.1 percent). Being in a union reduces this positive effect more for females than for males, although neither coefficient is significant in this case. This pattern holds for our most flexible models, where separate slope coefficients are estimated by gender and sector to focus on the effect of unionism. Here we see that even though females get significantly higher wage increases at promotion than do males in both the public and private sectors, the effect of unionism is more negative for females, especially so in the public sector - but again these coefficient estimates are statistically insignificant.

Compared with the early-career years, estimates of which are presented in Appendix 
Table A.5, we see an improvement in the returns to promotion for females in the public sector, although as we have noted such promotions are rare events. In the private sector - and noting that we should expect at least twice the wage return in later years for us to consider the earlycareer and mid-career results as of roughly equivalent magnitude - we see a decline in the returns to promotion for both males and females, comparing the last four wage growth specifications in Table 6 and Appendix Table A.5. And if we restrict our unionism definition and only consider union membership, we see that returns are lower per promotion in all specifications. These results are presented in Appendix Table A.6. They follow the pattern we observed when comparing the earnings equations (from Table 5 and Appendix Table A.4) for this specific definition of unions with the general version.

\section{Conclusions}

In the present treatment, we have sought to provide 'career-updated' estimates of the role of gender in promotions and of the consequences of such promotions. We build on past studies from the NLSY that, while offering an improvement on an earlier literature in terms of their representativeness and panel nature, only consider individuals at the early stages of their careers. Apart from being able to exploit data on promotion and earnings for individuals now at a later stage in their careers, we were also motivated to examine the role of unionism and sector since there were intriguing hints in NLSY studies and the wider literature that these institutions had negative 'effects' on promotion, and in some instances on earnings too.

Although our investigation of the role of gender, unionism, and sector has produced some (often interesting) diversions attendant upon the pattern of interaction coefficients, the main findings can be summarized as follows. First, in respect of internal mobility, females in mid- 
career appear more likely to be promoted than males in the private sector and no less likely to be promoted than males in the public sector - whereas in the earlier period they were much less likely than males to be promoted in the private sector. Among females, those in the public sector are more likely to be promoted than their private-sector counterparts. For its part, the union association with promotion is strongly negative for both genders in the public sector (although compared with the earlier period, we observe a major diminution in the negative effect of unionism in the private sector in the case of males). Second, wage levels increase with the number of promotions and are generally higher for females. But again they are reduced by unionism in the case of females in the public sector and for males in the private sector even if these are precisely the sectors where the union premium is strongly positive. Third, turning to wage growth contemporaneous with promotion, this association is both positive and well determined for both genders. The differential returns to gender are a function of sector: in the private sector males enjoy a slightly higher contemporaneous return to promotion whereas females do considerably better in the public sector. In the earlier period, in the altogether less likely event that women were to be promoted, they enjoyed somewhat higher returns than males in the private sector but not the public sector. Interestingly, in both periods, becoming a union member/covered by a collective agreement has a smaller effect than earning a promotion, and on this occasion current unionism plays no part in mediating the return to a promotion.

On net, and abstracting from the union effects which clearly point to the need for further study, we see these mid-career results as rather favorable to females. Indeed, some surprise may be occasioned by the very sharpness of these results, given that the returns to promotion might be expected to level off in mid-career, but this could be indicative of the favorable march of women detected over time in almost all studies. 


\section{References}

Acemoglu, Daren, and David H. Autor. 2011. "Skills, Tasks, and Technologies: Implications for Employment and Earnings.” In Orley Ashenfelter and David Card, eds., Handbook of Labor Economics, Volume 4, pp. 1043-1171. Amsterdam: Elsevier-North Holland.

Autor, David H., Frank Levy, and Richard J. Murnane. 2003. "The Skill Content of Recent Technological Change: An Empirical Exploration.” Quarterly Journal of Economics, 118(4), November 2003, 1279-1334.

Blau, Francine D., and Jed Devaro. 2007. "New Evidence on Gender Differences in Promotion Rates: An Empirical Analysis of a Sample of New Hires.” Industrial Relations, Vol. 46, No. 3, (July), pp. 511-547.

Blau, Francine D., and Lawrence M. Kahn. 1997. "Trends in the Gender Wage Differential in the 1990s.” Journal of Labor Economics, Vol. 15, No. 1 (January), pp. 1-42.

Booth, Alison L., Marco Francesconi, and Jeff Frank. 2003. “A Sticky Floors Model of Promotion, Pay, and Gender.” European Economic Review, Vol. 47, No.2 (April), pp. 295-322.

Booth, Jonathan E., John W. Budd, and Kristen M. Munday. 2010. "Never Say Never? Uncovering the Never-Unionized in the United States.” British Journal of Industrial Relations, Vol. 48, No. 1 (March), pp. 26-52.

Brown, James N. 1989. "Why Do Wages Increase with Tenure? On-the-Job Training and LifeCycle Wage Growth Observed Within Firms.” American Economic Review, Vol. 79, No. 5 (December), pp. 971-979.

Cabral, Roberto, Marianne A. Ferber, and Carole A. Green. 1981. "Men and Women in Fiduciary Institutions: A Study of Sex Differences in Career Development." Review of Economics and Statistics, Vol. 63, No. 4 (November), pp. 573-580.

Cannings, Kathy. 1988. "Managerial Promotion: The Effects of Socialization, Specialization, and Gender.” Industrial and Labor Relations Review, Vol. 42, No. 1 (October), pp. 77-88.

Cobb-Clark, Deborah A., and Yvonne Dunlop. 1999. “The Role of Gender in Job Promotions.” Monthly Labor Review, Vol. 122, No. 12 (December), pp. 32-38.

Cobb-Clark, Deborah A. 2001. "Getting Ahead: The Determinants and Payoffs to Internal Promotion for Young U.S. Men and Women.” Research in Labor Economics, Vol. 20, pp. 339-372. 
Devaro, Jed, and Dana Brookshire. 2007. "Promotions and Incentives in Nonprofit and For-Profit Organizations. 2007. Industrial and Labor Relations Review, Vol. 60, No. 3 (April), pp. 311-339.

DiPrete, Thomas A., and Whitman T. Soule. 1988. "Gender and Promotion in Segmented Job Ladder Systems.” American Sociological Review, Vol. 53, No.1 (February), pp. 26-40.

Fernandez, Roberto O., and Mabel Botelho Abraham. 2011. “Glass Ceilings and Glass Doors? Internal and External Hiring in an Organizational Hierarchy.” Unpublished paper, Cambridge, MA: MIT Sloan School of Management.

Gerhart, Barry A., and George T. Milkovich. 1989. "Salaries, Salary Growth, and Promotions of Men and Women in a Large, Private Firm.” In Robert T. Michael, Heidi Hartmann, and Brigid O’Farrell, eds., Pay Equity: Empirical Inquiries, pp. 23-43. Washington, DC: National Academy Press.

Ginther, Donna K., and Kathy J. Hayes. 1999. "Gender Differences in Salary and Promotion in the Humanities.” American Economic Review, Vol. 89, No. 2 (May), pp. 397-402.

Ginther, Donna K., and Kathy J. Hayes. 2003. "Gender Differences in Salary and Promotion for Faculty in the Humanities, 1977-95.” Journal of Human Resources, Vol. 38, No. 1 (Winter), pp. 3473.

Hersch, Joni , and W. Kip Viscusi. 1996. “Gender Differences in Promotion and Wages.” Industrial Relations, Vol. 35, No. 4 (October), pp. 461-472.

Jones, David R., and Gerald H. Makepeace. 1996. "Equal Worth, Equal Opportunities: Pay and Promotion in an Internal Labour Market.” Economic Journal, Vol. 106, No. 435 (March), pp. 401409.

Lazear, Edward P., and Sherwin Rosen. 1990. "Male-Female Wage Differentials in Job Ladders." Journal of Labor Economics, Vol. 8, No. 1, Part 2 (January), pp. S106-S123.

Macpherson, David A., and Barry T. Hirsch. 1995. "Wages and Gender Composition: Why Do Women’s Jobs Pay Less?” Journal of Labor Economics, Vol. 13, No. 1 (July), pp. 426-471.

McCue, Kristin. 1996. “Promotions and Wage Growth.” Journal of Labor Economics, Vol. 14, No. 2 (April), pp. 175-209.

McDowell, John M., Larry D. Singell, and James P. Ziliak. 2001.“ Gender and Promotion in the Economics Profession.” Industrial and Labor Relations Review, Vol. 54, No. 2 (January), pp. 224244. 
McDowell, Linda, and Gillian Court. 1994. "Missing Subjects: Gender, Power, and Sexuality in Merchant Banking.” Economic Geography, Vol. 70, No. 3 (July), pp. 229-251.

Meyers, Peter B., and Anastasia Osborne. 2005. "Proposed Category System for 1960-1970 Census Occupations.” Working Paper Series No. 238, Washington, DC: U.S. Bureau of Labor Statistics.

Olson, Craig A., and Brian E. Becker. 1983. "Sex Discrimination in the Promotion Process." Industrial and Labor Relations Review, Vol. 36, No. 4 (July), pp. 624-641.

Pekkarinen, Tuomas, and Juhana Vartiainen. 2006. “Gender Differences in Promotion on a Job Ladder: Evidence from Finnish Metalworkers.” Industrial and Labor Relations Review, Vol. 59, No. 2 (January), pp. 285-301.

Pergamit , Michael R., and Jonathan R. Veum. 1999. “What Is A Promotion?” Industrial and Labor Relations Review, Vol. 52, No. 4 (July), pp. 581-601.

Ransom, Michael, and Ronald L. Oaxaca. 2005. "Intrafirm Mobilty and Sex Differences in Wages.” Industrial and Labor Relations Review, Vol. 58, No. 2 (January), pp. 219-237.

Spilerman, Seymour. 1999. Organizational Structure, Determinants of Promotion, and Gender Differences in Attainment.” Social Science Research, Vol. 28, No. 2 (January), pp. 203-227

Spurr, Stephen J. 1990. "Sex Discrimination in the Legal Profession: A Study of Promotion." Industrial and Labor Relations Review, Vol. 43, No. 4 (April), pp. 406-417.

Spurr, Stephen J., and Glenn T. Sueuyoshi. 1994. “Turnover and Promotion of Lawyers.” Journal of Human Resources, Vol. 29, No. 3 (Summer), pp. 813-842.

Stewart, Lea P., and William B. Gudykunst. 1982. "Differential Factors Influencing the Hierarchical Level and Number of Promotions of Males and Females within an Organization.” Academy of Management Journal, Vol. 25, No. 3 (September), pp. 586-597.

Treble, John, Edwin van Gameren, Sarah Bridges, and Tim Barmby, 2001. "The Internal Economics of the Firm: Further Evidence from Personnel Data.” Labour Economics, Vol. 8, No. 5 (December), pp. 531-552.

Winter-Ebmer, Rudolf, and Josef Zweimüller. 1997. "Unequal Assignment and Unequal Promotion.” Journal of Labor Economics, Vol. 15, No. 1 (January), pp. 43-71. 
Table 1. Description of the Variables and Descriptive Statistics (1996-2008 waves of the NLSY79)




Table 2. Individual Background, Labor Market Experience, Employer and Job Characteristics; by Gender, Sector and Unionism

\begin{tabular}{|c|c|c|c|c|c|c|c|c|c|c|c|c|c|c|c|c|c|c|c|}
\hline & \multirow{3}{*}{ Variable } & \multicolumn{9}{|c|}{ Public Sector } & \multicolumn{9}{|c|}{ Private Sector } \\
\hline & & \multicolumn{3}{|c|}{$\begin{array}{l}\text { Not Union Member } \\
\text { and Uncovered }\end{array}$} & \multicolumn{3}{|c|}{$\begin{array}{l}\text { Union Member } \\
\text { and/or Covered }\end{array}$} & \multicolumn{3}{|c|}{ Union Member } & \multicolumn{3}{|c|}{$\begin{array}{c}\text { Not Union Member } \\
\text { and Uncovered }\end{array}$} & \multicolumn{3}{|c|}{$\begin{array}{r}\text { Union Member } \\
\text { and/or Covered }\end{array}$} & \multicolumn{3}{|c|}{ Union Member } \\
\hline \multirow{17}{*}{ Males } & & $\mathrm{N}$ & Mean & StD & $\mathrm{N}$ & Mean & StD & $\mathrm{N}$ & Mean & StD & $\mathrm{N}$ & Mean & StD & $\mathrm{N}$ & Mean & StD & $\mathrm{N}$ & Mean & StD \\
\hline & Age & 574 & 41.08 & 4.40 & 688 & 41.45 & 4.27 & 598 & 41.43 & 4.32 & 6425 & 41.00 & 4.47 & 1370 & 41.19 & 4.38 & 1168 & 41.13 & 4.37 \\
\hline & AFQT & 574 & 0.56 & 0.30 & 688 & 0.57 & 0.28 & 598 & 0.56 & 0.28 & 6425 & 0.55 & 0.29 & 1370 & 0.46 & 0.26 & 1168 & 0.44 & 0.25 \\
\hline & Education & 574 & 14.71 & 3.05 & 688 & 14.42 & 2.71 & 598 & 14.27 & 2.57 & 6425 & 13.71 & 2.70 & 1370 & 13.00 & 2.16 & 1168 & 12.68 & 1.67 \\
\hline & Black & 574 & 0.13 & 0.34 & 688 & 0.13 & 0.34 & 598 & 0.13 & 0.34 & 6425 & 0.09 & 0.29 & 1370 & 0.11 & 0.31 & 1168 & 0.11 & 0.32 \\
\hline & Married & 574 & 0.75 & 0.43 & 688 & 0.74 & 0.44 & 598 & 0.72 & 0.45 & 6425 & 0.67 & 0.47 & 1370 & 0.70 & 0.46 & 1168 & 0.70 & 0.46 \\
\hline & Number of children & 574 & 1.71 & 1.30 & 688 & 1.73 & 1.30 & 598 & 1.70 & 1.30 & 6425 & 1.65 & 1.32 & 1370 & 1.90 & 1.48 & 1168 & 1.91 & 1.49 \\
\hline & Tenure with current firm & 574 & 10.18 & 6.84 & 688 & 11.30 & 6.82 & 598 & 11.51 & 6.85 & 6425 & 7.62 & 6.57 & 1370 & 9.77 & 7.18 & 1168 & 10.41 & 7.25 \\
\hline & Prior labor market experience & 574 & 9.76 & 6.53 & 688 & 9.48 & 5.77 & 598 & 9.28 & 5.67 & 6425 & 12.55 & 6.71 & 1370 & 10.49 & 6.47 & 1168 & 9.91 & 6.32 \\
\hline & Medium firm & 574 & 0.19 & 0.40 & 688 & 0.31 & 0.46 & 598 & 0.32 & 0.47 & 6425 & 0.23 & 0.42 & 1370 & 0.29 & 0.45 & 1168 & 0.30 & 0.46 \\
\hline & Large firm & 574 & 0.22 & 0.42 & 688 & 0.19 & 0.39 & 598 & 0.18 & 0.39 & 6425 & 0.18 & 0.38 & 1370 & 0.28 & 0.45 & 1168 & 0.30 & 0.46 \\
\hline & State unemployment rate & 574 & 4.96 & 1.14 & 688 & 5.20 & 1.15 & 598 & 5.23 & 1.16 & 6425 & 4.96 & 1.13 & 1370 & 5.06 & 1.21 & 1168 & 5.07 & 1.21 \\
\hline & Non-Routine Cognitive Analytical & 574 & 0.60 & 0.91 & 688 & 0.44 & 0.93 & 598 & 0.41 & 0.93 & 6425 & 0.42 & 0.90 & 1370 & -0.01 & 0.76 & 1168 & -0.11 & 0.69 \\
\hline & Routine Cognitive & 574 & -0.22 & 0.96 & 688 & -0.08 & 0.93 & 598 & -0.06 & 0.93 & 6425 & -0.20 & 0.92 & 1370 & 0.09 & 0.80 & 1168 & 0.16 & 0.79 \\
\hline & Routine Manual & 574 & -0.36 & 0.93 & 688 & -0.14 & 0.90 & 598 & -0.08 & 0.89 & 6425 & 0.00 & 1.07 & 1370 & 0.60 & 0.97 & 1168 & 0.74 & 0.88 \\
\hline & Non-Routine Manual Physical & 574 & 0.03 & 1.12 & 688 & 0.38 & 1.22 & 598 & 0.50 & 1.19 & 6425 & 0.12 & 1.13 & 1370 & 0.76 & 1.04 & 1168 & 0.90 & 0.96 \\
\hline & Non-Routine Manual Personal & 574 & 0.29 & 1.17 & 688 & 0.36 & 1.15 & 598 & 0.34 & 1.15 & 6425 & -0.15 & 0.96 & 1370 & -0.66 & 1.02 & 1168 & -0.82 & 0.89 \\
\hline \multirow{16}{*}{ Females } & Age & 726 & 41.74 & 4.42 & 813 & 42.06 & 4.40 & 625 & 42.15 & 4.43 & 4969 & 41.16 & 4.45 & 603 & 41.21 & 4.47 & 432 & 41.16 & 4.50 \\
\hline & AFQT & 726 & 0.53 & 0.27 & 813 & 0.59 & 0.26 & 625 & 0.58 & 0.25 & 4969 & 0.51 & 0.27 & 603 & 0.45 & 0.28 & 432 & 0.45 & 0.27 \\
\hline & Education & 726 & 14.47 & 2.43 & 813 & 15.57 & 2.65 & 625 & 15.43 & 2.63 & 4969 & 13.55 & 2.37 & 603 & 13.82 & 2.62 & 432 & 13.55 & 2.44 \\
\hline & Black & 726 & 0.18 & 0.39 & 813 & 0.15 & 0.36 & 625 & 0.16 & 0.36 & 4969 & 0.11 & 0.31 & 603 & 0.22 & 0.42 & 432 & 0.19 & 0.39 \\
\hline & Hispanic & 726 & 0.13 & 0.33 & 813 & 0.05 & 0.22 & 625 & 0.05 & 0.22 & 4969 & 0.06 & 0.24 & 603 & 0.07 & 0.25 & 432 & 0.08 & 0.27 \\
\hline & Married & 726 & 0.63 & 0.48 & 813 & 0.66 & 0.47 & 625 & 0.65 & 0.48 & 4969 & 0.59 & 0.49 & 603 & 0.52 & 0.50 & 432 & 0.50 & 0.50 \\
\hline & Number of children & 726 & 1.65 & 1.19 & 813 & 1.61 & 1.17 & 625 & 1.61 & 1.18 & 4969 & 1.61 & 1.26 & 603 & 1.73 & 1.37 & 432 & 1.73 & 1.36 \\
\hline & Tenure with current firm & 726 & 8.52 & 6.46 & 813 & 10.60 & 6.99 & 625 & 11.05 & 7.11 & 4969 & 7.16 & 6.19 & 603 & 9.54 & 7.09 & 432 & 10.42 & 7.06 \\
\hline & Prior labor market experience & 726 & 10.57 & 6.60 & 813 & 9.08 & 6.27 & 625 & 8.77 & 6.31 & 4969 & 11.81 & 6.46 & 603 & 9.22 & 6.29 & 432 & 8.69 & 6.13 \\
\hline & Medium firm & 726 & 0.26 & 0.44 & 813 & 0.30 & 0.46 & 625 & 0.28 & 0.45 & 4969 & 0.26 & 0.44 & 603 & 0.36 & 0.48 & 432 & 0.39 & 0.49 \\
\hline & Large firm & 726 & 0.22 & 0.41 & 813 & 0.14 & 0.35 & 625 & 0.15 & 0.36 & 4969 & 0.20 & 0.40 & 603 & 0.24 & 0.43 & 432 & 0.28 & 0.45 \\
\hline & State unemployment rate & 726 & 5.00 & 1.11 & 813 & 5.18 & 1.23 & 625 & 5.23 & 1.23 & 4969 & 4.99 & 1.12 & 603 & 5.06 & 1.12 & 432 & 5.08 & 1.12 \\
\hline & Routine Cognitive & 726 & -0.03 & 1.00 & 813 & -0.16 & 1.04 & 625 & -0.10 & 1.08 & 4969 & 0.12 & 1.00 & 603 & 0.22 & 1.04 & 432 & 0.29 & 1.03 \\
\hline & Routine Manual & 726 & -0.64 & 0.64 & 813 & -0.70 & 0.68 & 625 & -0.67 & 0.68 & 4969 & -0.33 & 0.87 & 603 & 0.01 & 1.04 & 432 & 0.19 & 1.07 \\
\hline & Non-Routine Manual Physical & 726 & -0.74 & 0.68 & 813 & -0.76 & 0.80 & 625 & -0.73 & 0.82 & 4969 & -0.49 & 0.76 & 603 & -0.16 & 1.00 & 432 & 0.02 & 1.04 \\
\hline & Non-Routine Manual Personal & 726 & 0.47 & 0.88 & 813 & 0.81 & 0.94 & 625 & 0.79 & 0.94 & 4969 & 0.22 & 0.82 & 603 & 0.19 & 1.11 & 432 & 0.10 & 1.14 \\
\hline
\end{tabular}




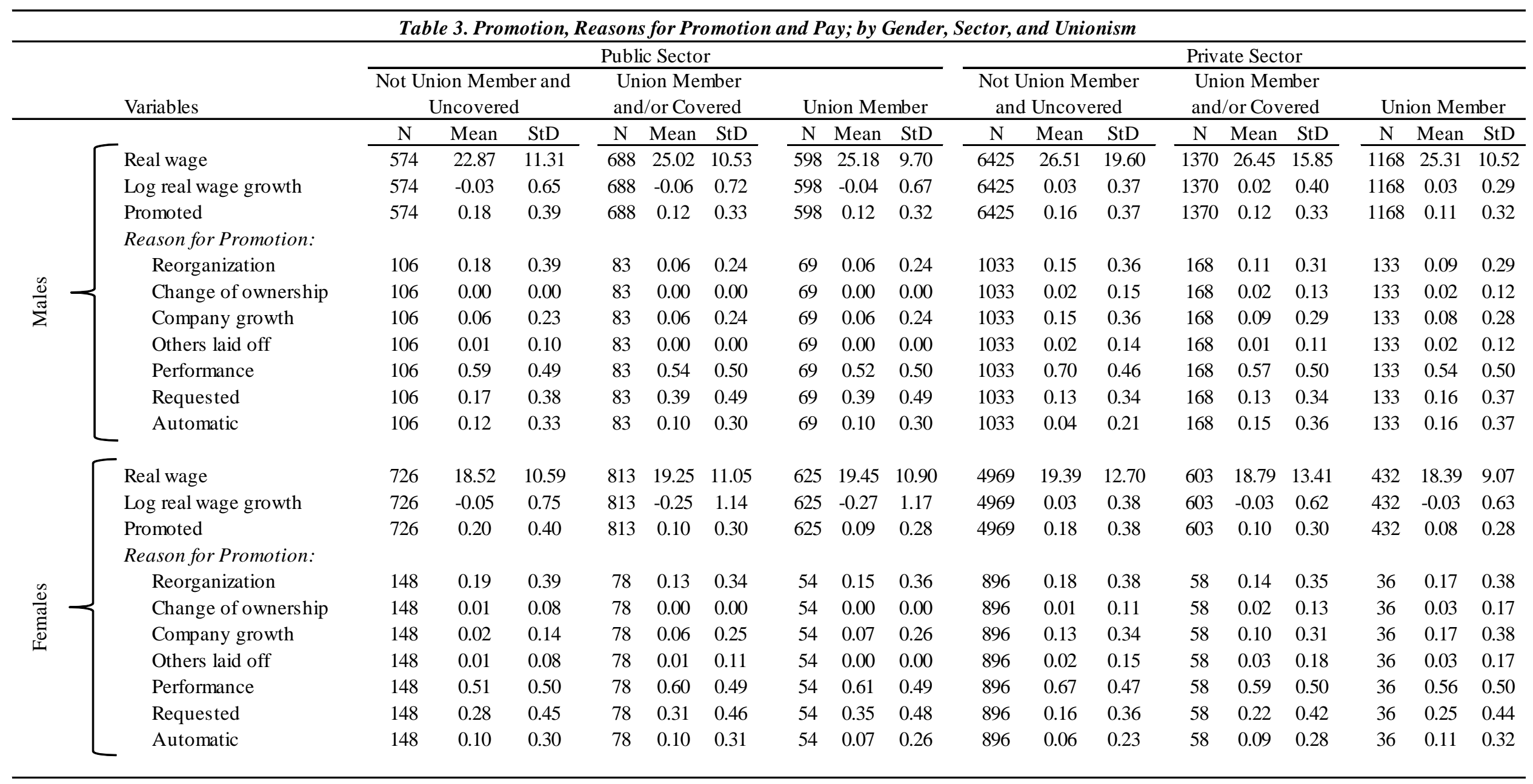


Table 4. Mid-Career Promotion Probability

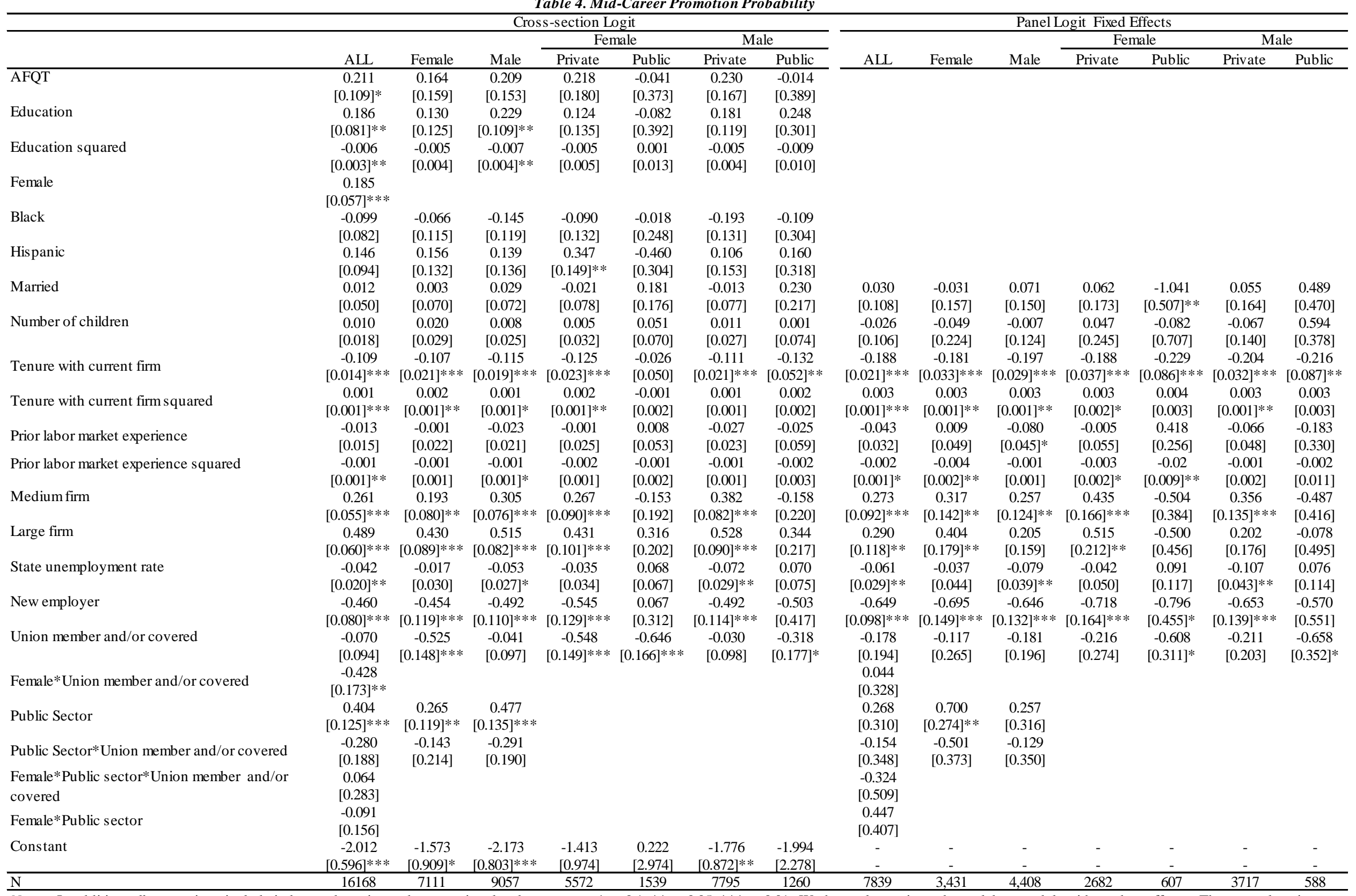

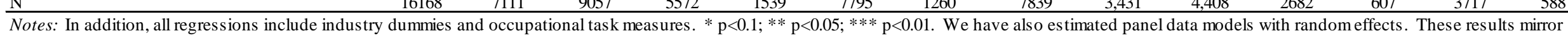
the cross-sectional estimates, but are not reported here since Hausman tests indicate that the RE model is not consistent (i.e. we cannot reject that the error $\mathrm{u}_{\mathrm{i}}$ is correlated with the covariates). 


\begin{tabular}{|c|c|c|c|c|c|c|c|}
\hline \multicolumn{8}{|c|}{ Table 5. Mid-Career Log Wages } \\
\hline & \multicolumn{7}{|c|}{ Panel OLS Fixed Effects } \\
\hline & \multirow[b]{2}{*}{ ALL } & \multirow[b]{2}{*}{ Female } & \multirow[b]{2}{*}{ Male } & \multicolumn{2}{|c|}{ Female } & \multicolumn{2}{|c|}{ Male } \\
\hline & & & & Private & Public & Private & Public \\
\hline \multirow[t]{2}{*}{ Married } & 0.025 & 0.026 & 0.024 & 0.012 & 0.197 & 0.000 & 0.104 \\
\hline & [0.018] & [0.032] & [0.019] & {$[0.022]$} & [0.143] & [0.017] & [0.092] \\
\hline \multirow[t]{2}{*}{ Number of children } & 0.025 & 0.034 & 0.003 & 0.05 & -0.035 & 0.018 & -0.092 \\
\hline & [0.017] & [0.045] & {$[0.016]$} & [0.032] & [0.167] & [0.014] & {$[0.076]$} \\
\hline \multirow[t]{2}{*}{ Tenure with current firm } & 0.001 & -0.011 & 0.011 & 0.011 & -0.098 & 0.020 & -0.049 \\
\hline & [0.004] & [0.007] & {$[0.004]^{* * *}$} & {$[0.005]^{* *}$} & {$[0.026]^{* * *}$} & {$[0.003]^{* * *}$} & {$[0.018]^{* * *}$} \\
\hline \multirow[t]{2}{*}{ Tenure with current firm squared } & 0.000 & -0.001 & 0.000 & 0.000 & 0.000 & 0.000 & 0.001 \\
\hline & {$[0.000]^{* * *}$} & {$[0.000]^{* * *}$} & {$[0.000]$} & {$[0.000]^{*}$} & {$[0.001]$} & {$[0.000]^{* * *}$} & {$[0.001]^{* *}$} \\
\hline \multirow[t]{2}{*}{ Prior labor market experience } & 0.000 & -0.020 & 0.018 & 0.004 & -0.146 & 0.022 & -0.016 \\
\hline & [0.005] & {$[0.010]^{* *}$} & {$[0.006]^{* * *}$} & [0.007] & {$[0.050]^{* * *}$} & {$[0.005]^{* * *}$} & [0.056] \\
\hline \multirow[t]{2}{*}{ Prior labor market experience squared } & 0.000 & 0.000 & 0.000 & 0.000 & 0.003 & 0.000 & 0.000 \\
\hline & {$[0.000]$} & {$[0.000]$} & {$[0.000]^{*}$} & {$[0.000]$} & [0.002] & {$[0.000]^{* *}$} & [0.002] \\
\hline \multirow[t]{2}{*}{ Medium Firm } & 0.032 & 0.057 & 0.012 & 0.060 & -0.099 & 0.031 & -0.009 \\
\hline & {$[0.016] * *$} & {$[0.028]^{* *}$} & [0.017] & {$[0.020]^{* * *}$} & {$[0.112]$} & {$[0.014]^{* *}$} & [0.086] \\
\hline \multirow[t]{2}{*}{ Large Firm } & 0.066 & 0.070 & 0.061 & 0.106 & -0.203 & 0.056 & 0.034 \\
\hline & {$[0.020]^{* * *}$} & {$[0.036]^{*}$} & {$[0.022]^{* * *}$} & {$[0.025]^{* * *}$} & {$[0.146]$} & {$[0.019]^{* * *}$} & [0.099] \\
\hline \multirow[t]{2}{*}{ State unemployment rate } & 0.007 & 0.019 & -0.003 & -0.002 & 0.006 & -0.006 & -0.011 \\
\hline & [0.005] & {$[0.009]^{* *}$} & [0.005] & [0.006] & [0.034] & [0.004] & [0.023] \\
\hline \multirow[t]{2}{*}{ New Employer } & 0.004 & -0.009 & 0.016 & -0.002 & -0.129 & 0.011 & 0.159 \\
\hline & {$[0.016]$} & {$[0.030]$} & [0.017] & {$[0.020]$} & {$[0.140]$} & [0.014] & [0.107] \\
\hline \multirow[t]{2}{*}{ Union member and/or covered } & 0.118 & 0.114 & 0.121 & 0.058 & 0.211 & 0.103 & 0.010 \\
\hline & {$[0.035]^{* * *}$} & {$[0.055]^{* *}$} & {$[0.028]^{* * *}$} & [0.035] & {$[0.127]^{*}$} & {$[0.023]^{* * *}$} & [0.102] \\
\hline \multirow[t]{2}{*}{ Female*Union member and/or covered } & 0.000 & & & & & & \\
\hline & {$[0.057]$} & & & & & & \\
\hline \multirow[t]{2}{*}{ Public Sector } & -0.243 & -0.123 & -0.214 & & & & \\
\hline & {$[0.057]^{* * *}$} & {$[0.060]^{* *}$} & {$[0.046]^{* * *}$} & & & & \\
\hline Public Sector*Union member and/or covered & -0.153 & -0.024 & -0.174 & & & & \\
\hline & {$[0.072]^{* *}$} & [0.081] & {$[0.057]^{* * *}$} & & & & \\
\hline Female*Public sector*Union member and/or covered & $\begin{array}{c}0.118 \\
{[0.098]}\end{array}$ & & & & & & \\
\hline Female*Public sector & 0.128 & & & & & & \\
\hline & {$[0.074]^{*}$} & & & & & & \\
\hline Number of promotions & 0.137 & 0.205 & 0.094 & 0.111 & 0.498 & 0.078 & 0.164 \\
\hline & {$[0.015]^{* * *}$} & {$[0.023]^{* * *}$} & {$[0.013]^{* * *}$} & {$[0.015]^{* * *}$} & {$[0.093]^{* * *}$} & {$[0.010]^{* * *}$} & {$[0.061]^{* * *}$} \\
\hline Number of promotions $*$ Public sector & -0.004 & -0.022 & -0.019 & & & & \\
\hline & {$[0.038]$} & [0.044] & {$[0.030]$} & & & & \\
\hline Number of promotions *Union member and/or covered & -0.113 & -0.066 & -0.118 & -0.037 & -0.209 & -0.107 & 0.020 \\
\hline & {$[0.030]^{* * *}$} & [0.064] & {$[0.024]^{* * *}$} & {$[0.040]$} & {$[0.106]^{* *}$} & {$[0.019]^{* * *}$} & [0.065] \\
\hline Number of promotions *Public sector*Union member & 0.148 & -0.116 & 0.162 & & & & \\
\hline and/or covered & {$[0.054]^{* * *}$} & [0.085] & {$[0.043]^{* * *}$} & & & & \\
\hline Number of promotions *Public sector*female & $\begin{array}{l}-0.025 \\
{[0.052]}\end{array}$ & & & & & & \\
\hline Number of promotions *Female & $\begin{array}{c}0.003 \\
{[0.021]}\end{array}$ & & & & & & \\
\hline Number of promotions *Union member and/or & 0.042 & & & & & & \\
\hline covered*female & {$[0.060]$} & & & & & & \\
\hline Number of promotions *Public sector*Union member & -0.266 & & & & & & \\
\hline and/or covered*female & {$[0.088]^{* * *}$} & & & & & & \\
\hline$\overline{\mathrm{R} 2}$ & 0.03 & 0.04 & 0.04 & 0.04 & 0.15 & 0.06 & 0.05 \\
\hline $\mathrm{N}$ & 16,168 & 7,111 & 9,057 & 5,572 & 1539 & 7,795 & 1262 \\
\hline
\end{tabular}




\section{Table 6. Mid-Career Promotions and Real Wage Growth (LogRealWage $t_{t}-$ LogRealWage $\left._{t-1}\right)$}

\begin{tabular}{|c|c|c|c|c|c|c|c|c|}
\hline \multirow{6}{*}{ Change from $t-1$ to $t$} & \multirow[b]{2}{*}{ Union member or covered $^{\dagger}$} & & & & & & & \\
\hline & & $\begin{array}{c}0.063 \\
{[0.018]^{* * *}}\end{array}$ & $\begin{array}{c}0.100 \\
{[0.032]^{* * *}}\end{array}$ & $\begin{array}{c}0.029 \\
{[0.019]}\end{array}$ & $\begin{array}{c}0.057 \\
{[0.027]^{* *}}\end{array}$ & $\begin{array}{c}0.153 \\
{[0.090]^{*}}\end{array}$ & $\begin{array}{c}0.032 \\
{[0.019]^{*}}\end{array}$ & $\begin{array}{c}0.033 \\
{[0.069]}\end{array}$ \\
\hline & Public sector employee $†$ & $\begin{array}{c}-0.064 \\
{[0.035]^{*}}\end{array}$ & $\begin{array}{c}-0.094 \\
{[0.055]^{*}}\end{array}$ & $\begin{array}{c}-0.016 \\
{[0.043]}\end{array}$ & $\begin{array}{c}-0.015 \\
{[0.051]}\end{array}$ & $\begin{array}{c}-0.015 \\
{[0.162]}\end{array}$ & $\begin{array}{c}0.048 \\
{[0.062]}\end{array}$ & $\begin{array}{c}-0.025 \\
{[0.113]}\end{array}$ \\
\hline & Public sector employee* union member or covered $^{\dagger}$ & $\begin{array}{l}-0.082 \\
{[0.069]}\end{array}$ & $\begin{array}{c}-0.014 \\
{[0.139]}\end{array}$ & $\begin{array}{l}-0.100 \\
{[0.070]}\end{array}$ & $\begin{array}{l}-0.060 \\
{[0.139]}\end{array}$ & $\begin{array}{c}-0.010 \\
{[0.353]}\end{array}$ & $\begin{array}{l}-0.100 \\
{[0.125]}\end{array}$ & $\begin{array}{c}-0.144 \\
{[0.159]}\end{array}$ \\
\hline & \multirow[t]{2}{*}{ Promoted } & 0.126 & 0.133 & 0.101 & 0.08 & 0.31 & 0.09 & 0.129 \\
\hline & & {$[0.020]^{* * *}$} & {$[0.029]^{* * *}$} & {$[0.016]^{* * *}$} & {$[0.018]^{* * *}$} & {$[0.117]^{* * *}$} & {$[0.014]^{* * *}$} & [0.083] \\
\hline \multirow[t]{8}{*}{ Promoted and is: } & Currently a union member or is covered & $\begin{array}{c}-0.042 \\
{[0.044]}\end{array}$ & $\begin{array}{l}-0.107 \\
{[0.122]}\end{array}$ & $\begin{array}{c}-0.031 \\
{[0.035]}\end{array}$ & $\begin{array}{c}-0.071 \\
{[0.077]}\end{array}$ & $\begin{array}{c}-0.239 \\
{[0.202]}\end{array}$ & $\begin{array}{c}-0.025 \\
{[0.034]}\end{array}$ & $\begin{array}{l}-0.027 \\
{[0.117]}\end{array}$ \\
\hline & Female and is currently a union member or is covered, and in public sector & $\begin{array}{c}-0.125 \\
{[0.134]}\end{array}$ & $\begin{array}{c}-0.114 \\
{[0.165]}\end{array}$ & & & & & \\
\hline & Female and is a union member or is covered & $\begin{array}{l}-0.045 \\
{[0.108]}\end{array}$ & & & & & & \\
\hline & Female & $\begin{array}{l}-0.023 \\
{[0.029]}\end{array}$ & & & & & & \\
\hline & Currently in public sector & $\begin{array}{l}-0.022 \\
{[0.048]}\end{array}$ & $\begin{array}{c}0.001 \\
{[0.068]}\end{array}$ & $\begin{array}{l}-0.032 \\
{[0.038]}\end{array}$ & & & & \\
\hline & Female and is currently in public sector & $\begin{array}{c}0.018 \\
{[0.073]}\end{array}$ & & & & & & \\
\hline & $\mathrm{R}^{2}$ & 0.01 & 0.02 & 0.01 & 0.02 & 0.06 & 0.03 & 0.02 \\
\hline & $\mathrm{N}$ & 10,842 & 4,565 & 6,277 & 3,540 & 1,025 & 5,350 & 927 \\
\hline
\end{tabular}

Notes: ${ }^{\dagger}$ Possible values for change in unionism and sector are $-1,0$ or 1 .

Promotion and promotion interactions are $0 / 1$ dummies. ${ }^{*} \mathrm{p}<0.1 ;{ }^{* *} \mathrm{p}<0.05 ; * * * \mathrm{p}<0.01$ 


\section{Appendix}

Table A.1. Early-Career Promotion Probability (Covered)

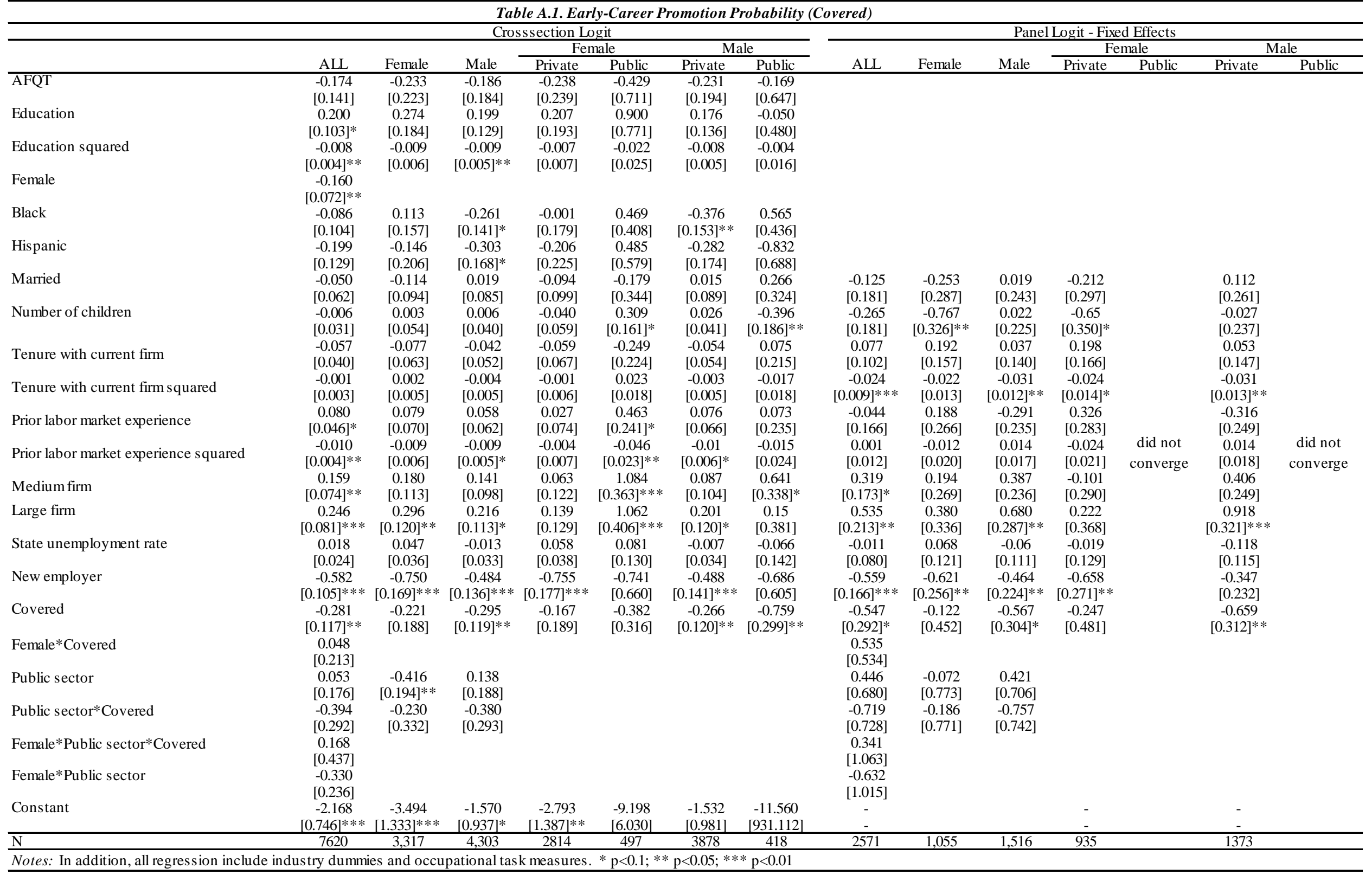




\begin{tabular}{|c|c|c|c|c|c|c|c|c|c|c|c|c|c|c|}
\hline & \multicolumn{7}{|c|}{ Cross-section Logit } & \multicolumn{7}{|c|}{ Panel Logit - Fixed Effects } \\
\hline & \multirow[b]{2}{*}{ ALL } & \multirow[b]{2}{*}{ Female } & \multirow[b]{2}{*}{ Male } & \multicolumn{2}{|c|}{ Female } & \multicolumn{2}{|c|}{ Male } & \multirow[b]{2}{*}{ ALL } & \multirow[b]{2}{*}{ Female } & \multirow[b]{2}{*}{ Male } & \multicolumn{2}{|c|}{ Female } & \multicolumn{2}{|c|}{ Male } \\
\hline & & & & Private & Public & Private & Public & & & & Private & Public & Private & Public \\
\hline \multirow[t]{2}{*}{$\overline{\mathrm{AFQT}}$} & 0.208 & 0.164 & 0.206 & 0.228 & -0.099 & 0.229 & -0.024 & & & & & & & \\
\hline & [0.109]* & {$[0.160]$} & [0.152] & {$[0.180]$} & [0.374] & [0.167] & [0.389] & & & & & & & \\
\hline \multirow[t]{2}{*}{ Education } & 0.203 & 0.155 & 0.239 & 0.137 & -0.032 & 0.187 & 0.269 & & & & & & & \\
\hline & {$[0.081]^{* *}$} & [0.125] & {$[0.110]^{* *}$} & [0.135] & [0.392] & {$[0.120]$} & [0.302] & & & & & & & \\
\hline \multirow{2}{*}{ Education squared } & -0.007 & -0.006 & -0.008 & -0.005 & -0.001 & -0.006 & -0.010 & & & & & & & \\
\hline & {$[0.003]^{* *}$} & {$[0.004]$} & {$[0.004]^{* *}$} & {$[0.005]$} & {$[0.013]$} & {$[0.004]$} & {$[0.010]$} & & & & & & & \\
\hline Female & $\begin{array}{c}0.172 \\
{[0.056]^{* * *}}\end{array}$ & & & & & & & & & & & & & \\
\hline \multirow[t]{2}{*}{ Black } & -0.106 & -0.079 & -0.146 & -0.109 & -0.03 & -0.193 & -0.113 & & & & & & & \\
\hline & {$[0.082]$} & [0.115] & [0.119] & {$[0.132]$} & {$[0.248]$} & [0.131] & [0.304] & & & & & & & \\
\hline \multirow[t]{2}{*}{ Hispanic } & 0.156 & 0.172 & 0.141 & 0.354 & -0.441 & 0.111 & 0.143 & & & & & & & \\
\hline & {$[0.094]^{*}$} & [0.132] & {$[0.136]$} & {$[0.149]^{* *}$} & [0.304] & [0.153] & {$[0.317]$} & & & & & & & \\
\hline Married & 0.011 & 0.001 & 0.029 & -0.023 & 0.181 & -0.012 & 0.220 & 0.032 & -0.027 & 0.070 & 0.060 & -0.976 & 0.056 & 0.466 \\
\hline & {$[0.050]$} & {$[0.070]$} & [0.072] & {$[0.078]$} & {$[0.176]$} & [0.077] & {$[0.218]$} & [0.108] & [0.157] & {$[0.150]$} & [0.173] & [0.513]* & [0.164] & {$[0.470]$} \\
\hline Number of children & 0.010 & 0.019 & 0.008 & 0.005 & 0.048 & 0.011 & -0.001 & -0.028 & -0.055 & -0.008 & 0.04 & -0.177 & -0.066 & 0.562 \\
\hline & [0.018] & [0.029] & [0.025] & {$[0.032]$} & {$[0.070]$} & [0.027] & [0.074] & [0.106] & [0.225] & [0.124] & [0.245] & [0.722] & [0.140] & {$[0.378]$} \\
\hline Tenure with current firm & -0.109 & -0.107 & -0.115 & -0.124 & -0.028 & -0.111 & -0.135 & -0.188 & -0.181 & -0.197 & -0.187 & -0.232 & -0.202 & -0.233 \\
\hline i enure witn current rirm & {$[0.014]^{* * *}$} & {$[0.021]^{* * *}$} & {$[0.019]^{* * *}$} & {$[0.023] * * *$} & {$[0.050]$} & {$[0.021]^{* * *}$} & {$[0.052] * * *$} & {$[0.022] * * *$} & {$[0.033]^{* * *}$} & {$[0.029] * * *$} & {$[0.037]^{* * *}$} & {$[0.087]^{* * *}$} & {$[0.032]^{* * *}$} & {$[0.086]^{* * *}$} \\
\hline Tenure with current firm squared & 0.001 & 0.002 & 0.001 & 0.002 & -0.001 & 0.001 & 0.002 & 0.003 & 0.003 & 0.003 & 0.003 & 0.004 & 0.003 & 0.003 \\
\hline & {$[0.001]^{* * *}$} & {$[0.001]^{* *}$} & [0.001]* & {$[0.001]^{* *}$} & [0.002] & [0.001] & [0.002] & {$[0.001]^{* * *}$} & {$[0.001]^{* *}$} & {$[0.001]^{* *}$} & {$[0.002]^{*}$} & [0.003] & {$[0.001]^{* *}$} & [0.003] \\
\hline Prior labor market experience & -0.013 & -0.002 & -0.023 & 0.000 & 0.006 & -0.027 & -0.023 & -0.040 & 0.013 & -0.078 & -0.004 & 0.426 & -0.064 & -0.146 \\
\hline Prior lador market experience & [0.015] & [0.022] & [0.021] & [0.025] & [0.053] & [0.023] & [0.059] & [0.033] & [0.049] & {$[0.045]^{*}$} & [0.055] & [0.261] & [0.048] & [0.332] \\
\hline Prior labor market experience & -0.001 & -0.001 & -0.001 & -0.002 & -0.001 & -0.001 & -0.002 & -0.002 & -0.004 & -0.001 & -0.003 & -0.020 & -0.001 & -0.003 \\
\hline squared & {$[0.001]^{* *}$} & {$[0.001]$} & {$[0.001]^{*}$} & {$[0.001]$} & {$[0.002]$} & {$[0.001]$} & [0.003] & {$[0.001]^{*}$} & {$[0.002]^{* *}$} & {$[0.001]$} & {$[0.002]^{*}$} & {$[0.009]^{* *}$} & {$[0.002]$} & {$[0.011]$} \\
\hline Medium firm & 0.264 & 0.191 & 0.311 & 0.273 & -0.168 & 0.385 & -0.141 & 0.265 & 0.295 & 0.258 & 0.431 & -0.612 & 0.361 & -0.454 \\
\hline 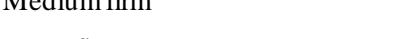 & {$[0.055]^{* * *}$} & {$[0.080]^{* *}$} & {$[0.076]^{* * *}$} & {$[0.090] * * *$} & [0.192] & {$[0.082]^{* * *}$} & {$[0.220]$} & {$[0.093]^{* * *}$} & {$[0.142] * *$} & {$[0.124]^{* *}$} & {$[0.166]^{* * *}$} & {$[0.390]$} & {$[0.135]^{* * *}$} & {$[0.414]$} \\
\hline Large firm & 0.499 & 0.439 & 0.523 & 0.440 & 0.321 & 0.533 & 0.353 & 0.288 & 0.392 & 0.209 & 0.503 & -0.500 & 0.215 & -0.101 \\
\hline & {$[0.060]^{* * *}$} & {$[0.089]^{* * *}$} & {$[0.083]^{* * *}$} & {$[0.101]^{* * *}$} & {$[0.202]$} & {$[0.091]^{* * *}$} & {$[0.217]$} & {$[0.118]^{* *}$} & {$[0.179]^{* *}$} & [0.159] & {$[0.211]^{* *}$} & {$[0.456]$} & {$[0.176]$} & [0.494] \\
\hline State unemployment rate & -0.041 & -0.016 & -0.052 & -0.035 & 0.072 & -0.071 & 0.074 & -0.061 & -0.040 & -0.078 & -0.044 & 0.092 & -0.107 & 0.085 \\
\hline & {$[0.020]^{* *}$} & {$[0.030]$} & {$[0.027]^{*}$} & [0.034] & [0.067] & {$[0.029] * *$} & {$[0.075]$} & {$[0.029]^{* *}$} & {$[0.045]$} & {$[0.039]^{* *}$} & [0.050] & [0.118] & {$[0.043]^{* *}$} & [0.114] \\
\hline New employer & -0.464 & -0.463 & -0.491 & -0.549 & 0.032 & -0.492 & -0.514 & -0.648 & -0.693 & -0.647 & -0.718 & -0.751 & -0.651 & -0.590 \\
\hline & {$[0.080] * * *$} & {$[0.118]^{* * *}$} & {$[0.110]^{* * *}$} & {$[0.129] * * *$} & {$[0.311]$} & {$[0.114]^{* * *}$} & {$[0.417]$} & {$[0.098]^{* * *}$} & {$[0.149]^{* * *}$} & {$[0.132]^{* * *}$} & {$[0.164]^{* * *}$} & [0.459] & {$[0.139]^{* * *}$} & {$[0.552]$} \\
\hline Union member & -0.145 & -0.629 & -0.110 & -0.643 & -0.710 & -0.078 & -0.362 & -0.345 & 0.100 & -0.335 & -0.010 & -1.236 & -0.458 & -0.596 \\
\hline & [0.104] & {$[0.184]^{* * *}$} & [0.107] & {$[0.185]^{* * *}$} & {$[0.178]^{* * *}$} & [0.109] & {$[0.185]^{*}$} & [0.245] & {$[0.368]$} & {$[0.248]$} & [0.384] & {$[0.412]^{* * *}$} & [0.258]* & [0.391] \\
\hline Female*Union member & -0.446 & & & & & & & 0.382 & & & & & & \\
\hline & {$[0.208]^{* *}$} & & & & & & & {$[0.443]$} & & & & & & \\
\hline Public Sector & 0.394 & 0.212 & 0.464 & & & & & 0.236 & 0.757 & 0.228 & & & & \\
\hline & {$[0.119]^{* * *}$} & {$[0.113]^{*}$} & {$[0.129]^{* * *}$} & & & & & {$[0.306]$} & {$[0.270]^{* * *}$} & {$[0.312]$} & & & & \\
\hline Public Sector*Union member & -0.252 & -0.056 & -0.265 & & & & & 0.045 & -1.301 & 0.060 & & & & \\
\hline & [0.196] & [0.249] & [0.199] & & & & & {$[0.400]$} & {$[0.484]^{* * *}$} & {$[0.402]$} & & & & \\
\hline Female*Public Sector*Union & 0.133 & & & & & & & -1.242 & & & & & & \\
\hline member & {$[0.315]$} & & & & & & & {$[0.627]^{* *}$} & & & & & & \\
\hline Female*Public Sector & $\begin{array}{c}-0.150 \\
{[0.146]}\end{array}$ & & & & & & & $\begin{array}{c}0.527 \\
{[0.400]}\end{array}$ & & & & & & \\
\hline Constant & -2.121 & -1.741 & -2.245 & -1.513 & -0.074 & -1.811 & -2.16 & - & & & - & - & - & - \\
\hline & {$[0.596]^{* * *}$} & {$[0.908]^{*}$} & {$[0.804]^{* * *}$} & [0.973] & [2.968] & {$[0.874]^{* *}$} & [2.287] & - & & & - & - & - & - \\
\hline $\mathrm{N}$ & 16168 & 7,111 & 9,057 & 5572 & 1539 & 7795 & 1260 & 7839 & 3,431 & 4,408 & 2682 & 607 & 3717 & 588 \\
\hline
\end{tabular}

Notes: In addition, all regressions include industry dummies and occupational task measures. ${ }^{*} \mathrm{p}<0.1 ; * * \mathrm{p}<0.05 ; * * * \mathrm{p}<0.01$. We have also estimated panel data models with random effects. These results mirror the cross-sectional estimates, but are not reported here since Hausman tests indicate that the RE model is not consistent (i.e. we cannot reject that the error ui is correlated with the covariates). 
Married

Number of children

Tenure with current firm

Tenure with current firm squared

Prior labor market experience

Prior labor market experience squared

Medium firm

Large firm

State unemployment rate

New employer

Covered

Female*Covered

Public sector

Public sector*Covered

Female*Public sector*Covered

Female*Public sector

Number of promotions

Number of promotions*Public sector

Number of promotions*Covered

Number of promotions* Public sector*Covered

Number of promotions*Female

Number of promotions*female*Covered

Number of promotions*Female*public sector

Number of promotions*female*Public sector*Covered






\begin{tabular}{|c|c|c|c|c|c|c|c|}
\hline \multicolumn{8}{|c|}{ Table A.4. Mid-Career Log Wages (Union Member) } \\
\hline & \multicolumn{7}{|c|}{ Panel Logit - Fixed Effects } \\
\hline & \multirow[b]{2}{*}{ ALL } & \multirow[b]{2}{*}{ Female } & \multirow[b]{2}{*}{ Male } & \multicolumn{2}{|c|}{ Female } & \multicolumn{2}{|c|}{ Male } \\
\hline & & & & Private & Public & Private & Public \\
\hline \multirow[t]{2}{*}{ Married } & 0.025 & 0.025 & 0.025 & 0.013 & 0.187 & 0.002 & 0.109 \\
\hline & {$[0.018]$} & [0.032] & [0.019] & [0.022] & {$[0.143]$} & {$[0.017]$} & [0.092] \\
\hline \multirow[t]{2}{*}{ Number of children } & 0.024 & 0.033 & 0.002 & 0.050 & -0.030 & 0.018 & -0.094 \\
\hline & [0.017] & [0.045] & {$[0.016]$} & [0.032] & {$[0.167]$} & {$[0.014]$} & {$[0.076]$} \\
\hline \multirow[t]{2}{*}{ Tenure with current firm } & 0.001 & -0.011 & 0.011 & 0.011 & -0.098 & 0.020 & -0.049 \\
\hline & {$[0.004]$} & {$[0.007]$} & {$[0.004]^{* * *}$} & {$[0.005]^{* *}$} & {$[0.026]^{* * *}$} & {$[0.003]^{* * *}$} & {$[0.017] * * *$} \\
\hline \multirow[t]{2}{*}{ Tenure with current firm squared } & 0.000 & -0.001 & 0.000 & 0.000 & 0.000 & 0.000 & 0.001 \\
\hline & {$[0.000]^{* * *}$} & {$[0.000]^{* * *}$} & {$[0.000]$} & {$[0.000]^{*}$} & [0.001] & {$[0.000]^{* * *}$} & {$[0.001]^{* *}$} \\
\hline \multirow[t]{2}{*}{ Prior labor market experience } & -0.001 & -0.020 & 0.018 & 0.004 & -0.152 & 0.022 & -0.015 \\
\hline & {$[0.005]$} & {$[0.010]^{* *}$} & {$[0.006]^{* * *}$} & [0.007] & {$[0.050]^{* * *}$} & {$[0.005]^{* * *}$} & {$[0.056]$} \\
\hline \multirow[t]{2}{*}{ Prior labor market experience squared } & 0.000 & 0.000 & 0.000 & 0.000 & 0.003 & 0.000 & 0.000 \\
\hline & {$[0.000]$} & {$[0.000]$} & {$[0.000]^{*}$} & {$[0.000]$} & {$[0.002]^{*}$} & {$[0.000]^{* *}$} & {$[0.002]$} \\
\hline \multirow[t]{2}{*}{ Medium Firm } & 0.030 & 0.055 & 0.011 & 0.060 & -0.106 & 0.029 & -0.007 \\
\hline & {$[0.016]^{*}$} & {$[0.028]^{*}$} & {$[0.017]$} & {$[0.020]^{* * *}$} & {$[0.112]$} & {$[0.014]^{* *}$} & {$[0.086]$} \\
\hline \multirow[t]{2}{*}{ Large Firm } & 0.065 & 0.069 & 0.060 & 0.106 & -0.204 & 0.054 & 0.036 \\
\hline & {$[0.020]^{* * *}$} & {$[0.036]^{*}$} & {$[0.022]^{* * *}$} & {$[0.025]^{* * *}$} & [0.146] & {$[0.019]^{* * *}$} & [0.099] \\
\hline \multirow[t]{2}{*}{ State unemployment rate } & 0.007 & 0.019 & -0.004 & -0.002 & 0.010 & -0.006 & -0.011 \\
\hline & {$[0.005]$} & {$[0.009]^{* *}$} & {$[0.005]$} & {$[0.006]$} & {$[0.034]$} & {$[0.004]$} & {$[0.023]$} \\
\hline \multirow{2}{*}{ New Employer } & 0.005 & -0.007 & 0.016 & -0.002 & -0.104 & 0.011 & 0.160 \\
\hline & {$[0.016]$} & {$[0.030]$} & {$[0.017]$} & {$[0.020]$} & {$[0.140]$} & {$[0.014]$} & {$[0.107]$} \\
\hline \multirow[t]{2}{*}{ Union member } & 0.135 & 0.143 & 0.142 & 0.058 & 0.206 & 0.128 & -0.042 \\
\hline & {$[0.042]^{* * *}$} & {$[0.068]^{* *}$} & {$[0.034]^{* * *}$} & {$[0.045]$} & {$[0.143]$} & {$[0.028]^{* * *}$} & {$[0.106]$} \\
\hline Female*Union member & 0.007 & & & & & & \\
\hline & {$[0.070]$} & & & & & & \\
\hline Public Sector & -0.250 & -0.126 & -0.224 & & & & \\
\hline & {$[0.055]^{* * *}$} & {$[0.058]^{* *}$} & {$[0.045]^{* * *}$} & & & & \\
\hline Public Sector*Union member & -0.159 & -0.024 & -0.178 & & & & \\
\hline & {$[0.077] * *$} & {$[0.093]$} & {$[0.061]^{* * *}$} & & & & \\
\hline Female*Public sector*Union member & 0.130 & & & & & & \\
\hline & {$[0.108]$} & & & & & & \\
\hline Female*Public sector & 0.129 & & & & & & \\
\hline & {$[0.071]^{*}$} & & & & & & \\
\hline Number of promotions & 0.129 & 0.204 & 0.085 & 0.111 & 0.498 & 0.070 & 0.159 \\
\hline & {$[0.015]^{* * *}$} & {$[0.023]^{* * *}$} & {$[0.013]^{* * *}$} & {$[0.015]^{* * *}$} & {$[0.092]^{* * *}$} & {$[0.010]^{* * *}$} & {$[0.059] * * *$} \\
\hline Number of promotions $*$ Public sector & 0.007 & -0.019 & -0.007 & & & & \\
\hline & [0.037] & [0.043] & [0.029] & & & & \\
\hline Number of promotions $*$ Union member & -0.059 & -0.09 & -0.068 & -0.052 & -0.301 & -0.051 & 0.035 \\
\hline & [0.036] & {$[0.090]$} & {$[0.029]^{* *}$} & [0.058] & {$[0.123]^{* *}$} & {$[0.023]^{* *}$} & [0.071] \\
\hline Number of promotions *Public sector*Union member & 0.099 & -0.174 & 0.115 & & & & \\
\hline & {$[0.060]^{*}$} & {$[0.110]$} & {$[0.048]^{* *}$} & & & & \\
\hline Number of promotions $*$ Female & 0.011 & & & & & & \\
\hline & {$[0.021]$} & & & & & & \\
\hline Number of promotions *Female*Union member & -0.031 & & & & & & \\
\hline & [0.083] & & & & & & \\
\hline Number of promotions *Female*Public sector & -0.031 & & & & & & \\
\hline & {$[0.051]$} & & & & & & \\
\hline Number of promotions *Female* Public sector*Union & -0.284 & & & & & & \\
\hline member & {$[0.109]^{* * *}$} & & & & & & \\
\hline $\mathrm{R} 2$ & 0.03 & 0.04 & 0.04 & 0.04 & 0.15 & 0.06 & 0.05 \\
\hline $\mathrm{N}$ & 16,168 & 7,111 & 9,057 & 5,572 & 1,539 & 7,795 & 1,262 \\
\hline
\end{tabular}




\begin{tabular}{|c|c|c|c|c|c|c|c|c|}
\hline \multicolumn{9}{|c|}{ Table A.5. Early-Career Promotion and Real Wage Growth (LogRealWage ${ }_{t}-$ LogRealWage $\left._{t-1}\right)($ Covered) } \\
\hline & & \multirow[b]{2}{*}{ ALL } & \multirow[b]{2}{*}{ Female } & \multirow[b]{2}{*}{ Male } & \multicolumn{2}{|c|}{ Female } & \multicolumn{2}{|c|}{ Male } \\
\hline & & & & & Private & Public & Private & Public \\
\hline \multirow[t]{4}{*}{ Change $t-1$ to $t$ : } & Covered $^{\dagger}$ & $\begin{array}{c}0.029 \\
{[0.021]}\end{array}$ & $\begin{array}{c}-0.003 \\
{[0.033]}\end{array}$ & $\begin{array}{c}0.048 \\
{[0.028]^{*}}\end{array}$ & $\begin{array}{c}-0.011 \\
{[0.045]}\end{array}$ & $\begin{array}{c}-0.036 \\
{[0.052]}\end{array}$ & $\begin{array}{c}0.048 \\
{[0.030]}\end{array}$ & $\begin{array}{c}0.018 \\
{[0.109]}\end{array}$ \\
\hline & Public sector employee $^{\dagger}$ & $\begin{array}{c}0.001 \\
{[0.039]}\end{array}$ & $\begin{array}{c}0.036 \\
{[0.056]}\end{array}$ & $\begin{array}{c}-0.014 \\
{[0.055]}\end{array}$ & $\begin{array}{c}0.018 \\
{[0.092]}\end{array}$ & $\begin{array}{c}0.046 \\
{[0.092]}\end{array}$ & $\begin{array}{c}-0.091 \\
{[0.079]}\end{array}$ & $\begin{array}{c}0.071 \\
{[0.126]}\end{array}$ \\
\hline & 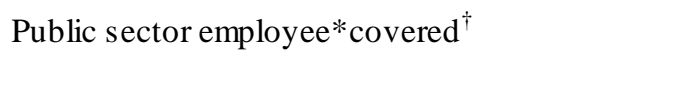 & $\begin{array}{c}-0.053 \\
{[0.076]}\end{array}$ & $\begin{array}{c}-0.222 \\
{[0.122]^{*}}\end{array}$ & $\begin{array}{c}0.062 \\
{[0.098]}\end{array}$ & $\begin{array}{c}-0.296 \\
{[0.223]}\end{array}$ & $\begin{array}{c}-0.091 \\
{[0.182]}\end{array}$ & $\begin{array}{c}0.122 \\
{[0.142]}\end{array}$ & $\begin{array}{c}0.092 \\
{[0.253]}\end{array}$ \\
\hline & Promoted & $\begin{array}{c}0.059 \\
{[0.020]^{* * *}}\end{array}$ & $\begin{array}{c}0.073 \\
{[0.022]^{* * *}}\end{array}$ & $\begin{array}{c}0.06 \\
{[0.022]^{* * *}}\end{array}$ & $\begin{array}{c}0.075 \\
{[0.023]^{* * *}}\end{array}$ & $\begin{array}{c}0.026 \\
{[0.070]}\end{array}$ & $\begin{array}{c}0.057 \\
{[0.021]^{* * *}}\end{array}$ & $\begin{array}{c}0.136 \\
{[0.112]}\end{array}$ \\
\hline \multirow[t]{6}{*}{ Promoted and is.. } & currently is covered & $\begin{array}{c}0.032 \\
{[0.051]}\end{array}$ & $\begin{array}{c}0.01 \\
{[0.093]}\end{array}$ & $\begin{array}{c}0.026 \\
{[0.053]}\end{array}$ & $\begin{array}{c}0.007 \\
{[0.095]}\end{array}$ & $\begin{array}{c}0.068 \\
{[0.123]}\end{array}$ & $\begin{array}{c}0.063 \\
{[0.056]}\end{array}$ & $\begin{array}{c}-0.09 \\
{[0.182]}\end{array}$ \\
\hline & female, is currently covered within public sector & $\begin{array}{c}0.012 \\
{[0.163]}\end{array}$ & $\begin{array}{c}0.03 \\
{[0.153]}\end{array}$ & & & & & \\
\hline & female and is covered & $\begin{array}{c}-0.028 \\
{[0.110]}\end{array}$ & & & & & & \\
\hline & female & $\begin{array}{c}0.013 \\
{[0.028]}\end{array}$ & & & & & & \\
\hline & currently in public sector & $\begin{array}{c}0.012 \\
{[0.061]}\end{array}$ & $\begin{array}{c}-0.034 \\
{[0.071]}\end{array}$ & $\begin{array}{c}0.009 \\
{[0.064]}\end{array}$ & & & & \\
\hline & female and is currently in public sector & $\begin{array}{c}-0.042 \\
{[0.097]} \\
\end{array}$ & & & & & & \\
\hline $\mathrm{R} 2$ & & 0.02 & 0.04 & 0.03 & 0.04 & 0.11 & 0.03 & 0.09 \\
\hline $\mathrm{N}$ & & 3,877 & 1,627 & 2,250 & 1,366 & 261 & 2,006 & 244 \\
\hline \multicolumn{9}{|c|}{ Notes: †Possible values for a change in unionism or sector are $-1,0$, and 1.} \\
\hline
\end{tabular}




\begin{tabular}{|c|c|c|c|c|c|c|c|c|}
\hline \multicolumn{9}{|c|}{ Table A.6. Mid-Career Promotion and Real Wage Growth (LogRealWage $t-$ LogRealWage $\left._{t-1}\right)$ (Union Member) } \\
\hline & & \multirow[b]{2}{*}{ ALL } & \multirow[b]{2}{*}{ Female } & \multirow[b]{2}{*}{ Male } & \multicolumn{2}{|c|}{ Female } & \multicolumn{2}{|c|}{ Male } \\
\hline & & & & & Private & Public & Private & Public \\
\hline \multirow[t]{4}{*}{ Change $t-1$ to $t:$} & Union member ${ }^{\dagger}$ & $\begin{array}{c}0.072 \\
{[0.024]^{* * *}}\end{array}$ & $\begin{array}{c}0.095 \\
{[0.045]^{* *}}\end{array}$ & $\begin{array}{c}0.055 \\
{[0.025]^{* *}}\end{array}$ & $\begin{array}{c}-0.017 \\
{[0.042]}\end{array}$ & $\begin{array}{c}0.179 \\
{[0.109]}\end{array}$ & $\begin{array}{c}0.074 \\
{[0.026]^{* * *}}\end{array}$ & $\begin{array}{c}0.006 \\
{[0.073]}\end{array}$ \\
\hline & Public sector employee ${ }^{\dagger}$ & $\begin{array}{c}-0.065 \\
{[0.035]^{*}}\end{array}$ & $\begin{array}{c}-0.093 \\
{[0.056]^{*}}\end{array}$ & $\begin{array}{l}-0.019 \\
{[0.043]}\end{array}$ & $\begin{array}{l}-0.013 \\
{[0.051]}\end{array}$ & $\begin{array}{c}-0.033 \\
{[0.162]}\end{array}$ & $\begin{array}{c}0.045 \\
{[0.062]}\end{array}$ & $\begin{array}{c}-0.024 \\
{[0.113]}\end{array}$ \\
\hline & Public sector employee*union member ${ }^{\dagger}$ & $\begin{array}{c}-0.079 \\
{[0.069]}\end{array}$ & $\begin{array}{c}0.000 \\
{[0.140]}\end{array}$ & $\begin{array}{c}-0.109 \\
{[0.070]}\end{array}$ & $\begin{array}{c}-0.126 \\
{[0.140]}\end{array}$ & $\begin{array}{c}0.061 \\
{[0.344]}\end{array}$ & $\begin{array}{c}-0.090 \\
{[0.125]}\end{array}$ & $\begin{array}{l}-0.127 \\
{[0.151]}\end{array}$ \\
\hline & Promoted & $\begin{array}{c}0.118 \\
{[0.019]^{* * *}}\end{array}$ & $\begin{array}{c}0.131 \\
{[0.028]^{* * *}}\end{array}$ & $\begin{array}{c}0.095 \\
{[0.016]^{* * *}}\end{array}$ & $\begin{array}{c}0.077 \\
{[0.018]^{* * *}}\end{array}$ & $\begin{array}{c}0.305 \\
{[0.111]^{* * *}}\end{array}$ & $\begin{array}{c}0.087 \\
{[0.014]^{* * *}}\end{array}$ & $\begin{array}{c}0.085 \\
{[0.078]}\end{array}$ \\
\hline \multirow[t]{6}{*}{ Promoted and is.. } & currently a union member & $\begin{array}{c}0.010 \\
{[0.047]}\end{array}$ & $\begin{array}{l}-0.097 \\
{[0.158]}\end{array}$ & $\begin{array}{c}0.014 \\
{[0.038]}\end{array}$ & $\begin{array}{c}-0.057 \\
{[0.100]}\end{array}$ & $\begin{array}{c}-0.323 \\
{[0.225]}\end{array}$ & $\begin{array}{c}-0.002 \\
{[0.037]}\end{array}$ & $\begin{array}{c}0.076 \\
{[0.118]}\end{array}$ \\
\hline & female, and is currently a union member in public sector & $\begin{array}{c}-0.201 \\
{[0.163]}\end{array}$ & $\begin{array}{l}-0.190 \\
{[0.201]}\end{array}$ & & & & & \\
\hline & female and is a union member & $\begin{array}{l}-0.098 \\
{[0.136]}\end{array}$ & & & & & & \\
\hline & female & $\begin{array}{l}-0.017 \\
{[0.028]}\end{array}$ & & & & & & \\
\hline & currently in public sector & $\begin{array}{c}-0.04 \\
{[0.048]}\end{array}$ & $\begin{array}{c}-0.002 \\
{[0.065]}\end{array}$ & $\begin{array}{c}-0.047 \\
{[0.038]}\end{array}$ & & & & \\
\hline & female and is currently in public sector & $\begin{array}{c}0.036 \\
{[0.071]}\end{array}$ & & & & & & \\
\hline $\mathrm{R} 2$ & & 0.01 & 0.02 & 0.02 & 0.02 & 0.06 & 0.03 & 0.02 \\
\hline $\mathrm{N}$ & & 10,842 & 4,565 & 6,277 & 3,540 & 1,025 & 5,350 & 927 \\
\hline
\end{tabular}

